\title{
Post Apokaliptik Temalı Video Oyunlarında Öteki'nin İnşası: Metro 2033 Adlı Dijital Video Oyununun Göstergebilimsel Analizi
}

Serkan Biçer (Dr. Öğr. Üyesi)

iD Fırat Üniversitesi Illetişim Fakültesi

sbicer@firat.edu.tr

Yeşim Şener (Doktora Öğrencisi)

(iD) Fırat Üniversitesi Sosyal Bilimler Enstitüsü

seneryesim41@gmail.com

Başvuru Tarihi: 21.04.2020

Yayına Kabul Tarihi: 22.06.2020

Yayınlanma Tarihi: 24.07.2020

https://doi.org/10.17680/erciyesiletisim.724809

Öz

Teknolojik gelişmelerin sonucunda, daha yaşanılabilir bir dünya söz konusu olsa da, zamanla bu durumun olumsuz etkileri de ortaya çımıştır. Bu olumsuz etkilerden biri de, doğaya verilen zararların distopik bir geleceği beraberinde getireceği düşüncesidir. Bu düşünce, dijital video oyunları içerisinde de kendine yer bulmuştur. Bu çerçevede, insanoğlunun doğaya verdiği zararlar, nükleer felaketler ve savaşlar; dijital video oyunlarında sıklıkla işlenen bir tema olmuştur. Söz konusu bu durum, geleceğe yönelik bir korku durumunu beraberinde getirmiștir. Bu korku durumu, biz ve ötekiler arasında bir ayrışmayı da zorunlu kılarak, post apokaliptik dünyada distopik bir yaşamın izlerini de taşımaya başlamıştır. Bunun sonucunda, post apokaliptik dijital video oyunlarında, distopik yaşama yönelik bir ötekinin oluşturulması söz konusu olmuştur. Genel bir anlatımla; distopik bir dünya çerçevesinde, post apokaliptik temalı gelecek kurgusunda bir öteki yaratılmaktadır. Yaratılan bu öteki, derhal yok edilmesi gereken bir varlık olarak sunulmaktadır.

$\mathrm{Bu}$ çalışmanın temel çıkış noktası; post apokaliptik dijital video oyunlarında inşa edilen ötekini yeniden düşünmeye yöneliktir. Bu amaçla, Metro 2033 adlı dijital video oyunu araștırma kapsamına alınarak, nitel araștırma modellerinden durum analizi modeliyle desenlenmiştir. Elde edilen veriler ise; Barthes'in düzanlam ve yananlamsal göstergebilimsel çözümleme yöntemiyle analiz edilmiştir. Bu çalışmanın sonucunda; biz teknolojiye sahip, ötekilerden kaçarak ve hayatta kalmak için heterotopik bir alana yönelmiş karakterler olarak kurgulanırken; ötekilerin ise, teknolojiden yoksun, ilkel, tehlikeli, ürkütücü, yabani yaratık veya kurgusal hayvani bir varlık olarak inşa edildiği tespit edilmiştir.

Anahtar Kelimeler: Post Apokaliptik Dünya, Öteki, Göstergebilim, Video Oyunları, Metro 2033. 
Research Article

\title{
Construction of "The Other" in Post- Apocalyptic Video Games: Semiotic Analysis of the Digital Video Game "Metro 2033"
}

\author{
Serkan Biçer (Asst. Prof. Dr.) \\ Firat University Faculty of Communication \\ sbicer@firat.edu.tr \\ Yeşim Şener (Ph.D. Student) \\ iD Firat University Institute of Social Sciences \\ seneryesim41@gmail.com
}

Date Received: 21.04.2020

Date Accepted: 22.06 .2020

Date Published: 24.07.2020

https://doi.org/10.17680/erciyesiletisim.724809

\begin{abstract}
As a result of technological developments, although a more livable world is in question, negative effects of this situation have emerged over time. One of these negative effects is the idea that harm to nature will bring a dystopic future. This idea has found itself in digital video games. In this framework, the human damage, nuclear disasters and wars; It has been a theme frequently handled in digital video games. This situation brought with it a fear of the future. This fear situation, by necessitating a separation between us and the others, began to bear the traces of a dystopian life in the postapocalyptic world. As a result, in postapocalyptic digital video games, the creation of another for the dystopic life has been in question. In a general expression; Within the framework of a dystopian world, another is created in the post-apocalyptic-themed future fiction. This other created is presented as an asset that must be destroyed immediately.

The main starting point of this study; is intended to rethink the other built in postapocalyptic digital video games. For this purpose, the digital video game called Metro 2033 was included in the research and was designed with a situation analysis model from qualitative research models. The data obtained are; It was analyzed by Barthes' method of arrangement and combustion, semiotic analysis. As a result of this study; while we are constructed as technology characters, escaping from others and turning to a heterotopic field for survival; others have been found to be built as a primitive, dangerous, spooky, wild creature or fictional animal.
\end{abstract}

Keywords: Postapocalyptic World, Other, Semiotics, Video Games, Metro 2033. 


\section{Giriş}

21. Yüzyılda teknolojinin gelişmesiyle birlikte yeni bir yaşam tarzına zemin hazırlanmıștır. Bu yaşam tarzında; popüler kültür, dil, tüketim, kimlik bașta olmak üzere gelecek kurgusu üzerinde farklı yorumlar getirilerek, bireylere çeşitli mesajlar iletilmeye başlanmıştır. Postmodern dünyada medya aracılığıyla, gelecek yaşam öyküsü üzerine bir kurgu inşa edilirken genellikle; ölüm, kan, şiddet, vahşet, felaket, yıkım, savaş, silah, bulaşıcı hastalıklar, ekolojik felaketler gibi olumsuz içerikli mesajlar üretildiği ve bu mesajların hedef kitleye aktarıldığı bilinmektedir. Bu gelecek kurgusu; post apokaliptik (kıyamet sonrası) bir süreci içerisine alarak teknoloji aracılığıyla distopik (karanlık veya anti ütopya) bir dünyayı yaratmaktadır.

İnsanoğlunun ortak kaderi olan yok olma korkusu postmodern dünyada teknolojik ilerlemelerden dolayı daha da artmıştır. Bu yok olma korkusuna karşılık yaşamak için öldür politikası söz konusu olmuştur. Bu çerçevede, dijital ortamlarda insanoğlu; kendisini rahatlatacak ve korkusunu kısmen de olsa ortadan kaldıracak bir alan inşa etmiştir. Zira, bu alanlar, korku durumunu da yansıtacak bir şekilde post apokaliptik bir sanal dünya içerisinde kendine bulmuştur. Böylece, sanal dünyadaki bu korku durumu, video oyunlarda da kendine yer bularak bu alanda bir öteki yaratılmıștır. Dolayısıyla, post apokaliptik dijital video oyunlarında öteki olarak tanımlanan varlıklar distopik bir dünyanın korku unsuru olup, ötekine yönelik nefret duygularını da inşa edilmiştir. Bu nefret biçimi; yok etme durumunu beraberinde getirerek bir tür ayrıșma politikalarını da meşru kılmıștır.

Bilindiği üzere, insanoğlunun yeryüzünde yaşamaya başladığı ilk dönemlerden itibaren; felaket, yıkım, savaş, ölüm, korku vb. gibi durumlarla karşı karşıya kalması sonucu bir ayrışma politikası ortaya atılmıştır. Söz konusu bu durumun günümüze de yansımasıyla birlikte, bu durum sanal ortamlarda da yer almıştır. Bu doğrultuda, birçok sanal platformlarda olduğu gibi, dijital video oyunlarında da biz ve öteki çerçevesinde toplumsal ve mekânsal ayrışma oldukça sık işlenmeye başlanmıştır. Zira, post apokaliptik temalı bilim kurgu sahnelerinde; insan nüfusunun artmasıyla birlikte kaynakların tükenmesi, yok olma tehlikesi, nükleer felaketler vb. gibi durumlara dair mesajların oldukça fazla iletildiği söylenebilmektedir. Bu gibi durumlarla birlikte gelecekte yaşanan felaket ve korku durumu inşa edilerek bunun sonucunda ötekilerin öldürülmesinin gerektiği de gösterilmektedir (Boz, 2018). Söz konusu bu durumda, bir steril alan yaratılmaktadır (Lizardi, 2009).

Bu çalışmanın amacı; post apokaliptik dijital ortamlarda teknolojik ilerlemelerin getirmiş olduğu distopik sonuçların, video oyunlarında öteki bağlamında nasıl sunulduğunun ve ötekinin nasıl tanımlandığının tespit edilmesidir. Bu amaçla, literatürden yararlanılmış ve ilgili çalışmalar incelenmiştir. İncelenen bazı çalışmalara göre (Witheford ve Sharman, 2005; Rawi, 2013; De Riso, 2013; Yorulmaz, 2018; Güngör, 2017) sanal oyunlarda; kültürel, ideolojik, etnik, sınıf farklılıkları, nefret söylemi, ayrımcılık, terör, şiddet vb. gibi birçok unsur barınmaktadır. Post apokaliptik içerikli dijital video oyunları ve ötekinin konumuyla ilgili ise bazı çalışmalar (Cornea , 2007; Sunato ve Karadon, 2013) görülmesiyle birlikte; bu üç kavramın (post apokaliptik- öteki- dijital video oyunları) bir arada olduğu çalışmaların oldukça sınırlı olduğu görülmüştür. Post apokaliptik temalı dijital video oyunlarında yok edilmeye çalışılan ve öteki olarak konumlandırılan karakterlerin kim olduğunun yani neye karşılık geldiğinin analiz edilmesi doğru olacaktır. Zira, post apokaliptik, öteki ve dijital video oyunları şeklindeki kavramlar birbiriyle ilintili olup, bu kavramların bütüncül bir şekilde analiz edilmesinin bilimsel veri oluşturması 
bakımından gerekli olduğu ileri sürülebilmektedir. $\mathrm{Bu}$ çerçevede çalışmanın, daha sonra yapılacak olan ilgili çalışmalara rehber olabilmesi açısından önem arz ettiği söylenebilmektedir.

\section{İlgili Çalışmalar}

Wildt ve ark.'nın (2018) "Sizden Daha Büyük Şeyler: Oyunlarda Klyamet Sonrası Din" adlı çalışmasında Fallout 3 ve Horizon: Sıfır Şafak adlı iki oyun örnek olay incelemesiyle ele alınmıştır. Bu doğrultuda, modern teknolojinin kıyamet sonrası oyunların kutsal bir nesnesi haline geldiği ortaya çıkarılmıştır. Genel bir ifadeyle; Wildt ve ark.',nın tekno-din temalı çalışmasında, post apokaliptik temalı video oyunlarında dini inanç ve ibadet davranışlarının olduğu, ancak bu davranışların mitolojik tanrılara ya da doğal dünyaya değil; kıyameti meydana getiren teknolojik aygıtlara uygulandığı iddia edilmiştir.

Yorulmaz'ın (2018) "Dijital Oyunlarda Müslüman Temsili” adlı çalıșmasında; Batı tarafından üretilen oyunlarda Müslümanların, terörizmle özdeșleștirilerek temsil edildiği ortaya çıkarılmıştır. Özellikle FPS (First Person Shooter: Nişan alma/Ateş Etme) konusundaki oyunlar, mekânsal olarak Ortadoğu'da geçtiği ve düşmanın ise açıkça Müslümanlar olarak tasarlandığı tespit edilmiştir.

Dolu ve ark'nın (2010) “Şiddet İçerikli Video Oyunlarının Çocuklar ve Gençler Üzerindeki Etkileri: Saldırganlık, Şiddet ve Suça Dair Bir Değerlendirme" adlı çalışmasında; çocuk ve gençlerin, şiddet içerikli video oyunlarına kolaylıkla ulaşması sonucu, şiddete ve suça daha fazla yöneldikleri görülmüştür. Yani, bu çalışmaya göre; şiddet ve suç içerikli video oyunları, bireyler üzerinde etkide bulunduğunu ortaya çıkarmıştır.

Boz’un (2018) "2000 Sonrası Amerikan Post-Apokaliptik Bilimkurgu Sinemasında Kıyamet Ideolojisi" adlı doktora tez çalışmasında; küresel ısınma, felaket, istila vs. gibi belirlenen ölçütler çerçevesinde, ele alınan filmlerin betimsel analizi yapılmıștır. Yapılan araştırma sonucunda, filmlerde yer alan yıkım olgusunun modern toplumsal yaşamdaki sorunların bir dışavurumu ve çözümü olarak tasarlandığı ve bu doğrultuda yeni bir toplumsal yapılanmanın sunulmaya çalışıldığı ortaya çıkarılmıştır.

Yürür'ün (2015) “Bilimkurgu Sinemasında Güncel Korkuların Yansıması: Post Apokaliptik Filmler" adlı çalışmasında; betimsel içerik analizinden yararlanılmış ve tarihsel süreç içerisinde değișen post apokaliptik sinemanın döngüsel ve devinimsel yapısına örnekler üzerinden yer verilirken, materyalist eleștirel yaklașımdan da yararlanılmıștır. $\mathrm{Bu}$ çalışmayla, post apokaliptik bilimkurgu sinemasında güncel korkuların yansıtıldığı tespit edilmiştir.

Bilici'nin (2007) "Hollywood Filmlerindeki Apokaliptik Temalar: Sinema, Popüler Kültür ve Din" adlı makalesinde Apocalypse Now ve Twelve Monkeys filmleri popüler kültür, din ve modernite bağlamında değerlendirilmiştir. İncelenen filmlerde kullanılan kodların Hıristiyan geleneğinde neyi çağrıştırdıkları ve dinsel algıyı nasıl dönüştürdükleri incelenmiştir. Yapılan inceleme sonucunda, post apokaliptik sahnelerin, dinsel bağlantısının da olduğu tespit edilmiştir.

Lizardi’nin (2009) “Öteki'nin İstilasını Bastırmak: Kıyamet Sonrası Yabancı Atıcı Çağdaş Kültürel Tutumları Ele Alan Video Oyunları” adlı çalışmasında; modern bir dünyada yaşanan kaygılar sonucunda yabancının hegemonik bir kitle tarafından kovulması gerektiği üzerinde durulmaktadır. Bu bakımdan, kültürel olarak farklı olanların gizli bir korku ve güvensizliği oluşturduğu ortaya çıkarılmıştır. 
Rawi'nin (2013) "Video games, terrorism and Jihad 3.0 of ISIS” adlı çalışmasında YouTube üzerinden oynanan ve IŞID terör örgütünün; şiddet, ölüm, kan, cihat vb. gibi unsurları, sanal ortamda oyunculara aktardığı tespit edilmiştir.

De Riso'nun (2013) "Affect and Agency in Modern Warfare Videogames: Feeling the Muslim Enemy (Modern Savaş Video Oyunlarında Etki ve Ajans: Müslüman Düşmanı Hissetmek" adlı çalışmasında, savaş oyunlarının yaratılması üzerinde durulmuştur. Bu çalışmayla, video oyunlarında Müslümanların düşman olarak tasvir edildiği ortaya çıkarılmıştır.

Post apokaliptik, öteki ve dijital video oyunları kavramlarıyla sınırlandırılan çalışmalarda genel olarak görülmektedir ki, araştırmalar genellikle; ayrımcılık, nefret, ırkçılık, şiddet, milliyetçilik, ideoloji, cinsiyet ayrımcılığı, popüler kültür, modernleşme ve tekno-din çerçevesinde ele alınmaktadır. Ancak bu çalışmada ise; öteki; ayrışma, heterotopya, bedensel tasvir, teknolojiye sahip olma, hegemonik güç gibi kavramlarla değerlendirilecektir. Böylece, post apokaliptik dijital video oyunlarında inşa edilen öteki ${ }^{1}$ yeniden düşünülecektir.

\section{Kuramsal Çerçeve}

\section{Postmodern Dünya ve Dijital Video Oyunları}

Günümüzde, top, ip veya taş gibi geleneksel oyun malzemelerinin yerini teknolojik cihazlar almıştır. Artık, yaş fark etmeksizin her bireyin oynayacağ çeşitli türlerdeki sanal oyunlar dijital ortamlarda yerini bulmuştur. Bu sanal oyunlar, dijital ortamın desteğiyle var olan, çoğunda canlandırılmış bir grafikle desteklenen, oyuncunun el ve göz koordinasyonuna ihtiyaç duyulan, belirli alt disiplinlere sahip olan dijital simülasyonların tümünü kapsayan çok çeşitli bir ortam olarak sunulmuştur (Denizel, 2012, s. 109-110).

21. yüzyılda, çok çeşitli bir ortam olarak dijital oyun oynama kültürünün yaygınlaşması sonucunda, sanal oyunlar postmodernizmle de ilişkilendirilmeye başlanmıştır (Güngör, 2017, s. 197). Bu noktadan hareketle, postmodern dönemde; dijital oyunlara yeni anlamlar yüklenmiştir. Artık dijital oyunlar, sadece bireylerin zamanlarını geçirmesi ya da eğlenmesi amacıyla üretilmemektedir. Ayrıca; ideolojik, dinsel, kültürel, ekonomik vb. gibi çeşitli mesajları iletmek amacıyla da üretilmektedir. Böylece; post modern dünyada oyun oynama kültürünün değiştiği ileri sürülebilmektedir.

Bu değişimlerden biri de ayrıştırıcı politikaların söz konusu olmasıdır. Zira, postmodern bir dünyanın formülü olan farklılık dijital oyunlarda da hissedilmektedir. Böylece, bir ayrıştırıcı politika inşa edilmektedir. Çağımızda, dijital video oyunlarıyla birlikte birçok etnik, dini grup, ülke vb. gibi unsurlar potansiyel teröristler olarak sunulmaktadır (Ersoy, 2014). Özellikle video oyunlarını üreten firmaların savaş temasını oldukça sık kullandığı bir gerçektir. Bu anlamda, dijital oyunlarda genellikle; ölüm, şiddet, nefret, ayrımcılık; gelecek korkusu, yok olan bir dünya ve kaçış unsurlarını da kapsayan içerikler üretilmeye başlanmıştır. Bu içeriklerde, potansiyel bir düşman olarak bir öteki yaratılmaktadır.

\section{Öteki'nin İnşası}

Post apokaliptik dijital video oyunlarında, inşa edilen ötekini anlamak için öncelikle temsil kavramına değinilmesi gerekmektedir. Bir $a$ bir de $b$ varken; a olmadığında $b$ eğer $a$ ya ikame ediyorsa; $b$ kavramı, $a$ kavramını temsil ediyor demektir (Varol, 2016, s. 13). Bu çerçevede, temsil; bir şey yokken diğer bir şeyin onu ikame etmesidir. Hall'e (2017, s.23) göre temsil kavramı; diğer bireylere dünya hakkında anlamlı bir şeyler söylemek ya da dünyayı anlamlı kılacak şekilde dili kullanmaktır. Söz konusu bu süreçte, 
bir șey temsil edilirken dil aracılığıyla kullanılan kodların önemi de yadsınamaz. Ayrıca, kodların neyi nasıl temsil ettiği yine dil sayesinde bir anlam kazanmaktadır. Temsil kavramı değerlendirilirken, ayrıca tipleme ve klişeleştirme kavramlarını da göz ardı etmemek gerekmektedir.

Richard Dyer; tipleme ve klişeleștirme arasında bir ayrım yapmaktadır. Onun deyimiyle; dünyanın, nesnelerin, bireylerin veya olayların genel sınıflandırıcı şemaları beyine yerleştirerek anlaşılır. Örneğin; üzerine bacakların koyulduğu bir nesne masa olarak bilinç tarafından anlamlandırılmaktadır. Bu anlamlandırma, beyinin içerisinde yer alan genel konsepte uyumlu bir şekilde ortaya çıkmaktadır. Bu doğrultuda, tipleme olarak adlandırılan davranış uygulanmış olmaktadır. Klișeleștirmeye bakıldığında ise; Foucault tarafından güç/bilgi türünde bir oyun olarak adlandırılan şey olarak ortaya çıkmaktadır. İnsanlar belirli bir norma göre sınıflandırılır ve dışarıda kalan başkası/yabancı olarak değerlendirilir. Böylece, klişeleştirme bir ayırma stratejisini uygular (Aktaran, Hall, 2017, s. 333-334). Normal olanı normal olmayandan ayırır. Ardından farklı olanı dışlar. Yani; klișeleștirmenin özelliklerinden biri de dışlama pratiğidir. Söz konusu bu süreçte, sembolik bir biçimde sınırlar sabitlenir ve ait olmayan her şey dışarıda bırakılır.

$\mathrm{Bu}$ dışlama pratiğiyle, biz ve ötekiler arasında bir tür kimlik tanımlama biçimini de beraberinde gelir. Zira kimlik; bizimle aynı konumda olan kişilerle benzerlikleri; aynı konumda olmayan kişilerleyse farklılıkları tanımlamaktadır (Varol, 2016, s. 47). Kimliğin meydana gelmesinden, bireyin kendini tanımlamasına kadar geçen süreçte ötekinin de tanımlanması gerekmektedir. Zira bu iki kavram (kimlik ve öteki); iki taraflıdır ve birbirini beslemektedir (Devrani, 2017, s. 927-928).

Kimliğin varolması için farklılığa gereksinim duyulmaktadır. Söz konusu bu durumda, biz kendini güven altına almak için farklılığı ötekine dönüştürmektedir (Connolly, 1995, s. 93). Yani, burada var olan farklılık aslında bir ötekini yaratma fikrini geliştirmektedir (Selçuk, 2012, s. 83). Bauman (2013, s.131) ise farklılık kavramına; özgürlük, eşitlik ve kardeşlik modernliğin sloganıken; özgürlük, hoşgörü ve farklılık ise postmodernliğin ateşkes formülü olduğunu belirtmektedir.

Dolayısıyla, postmodern bir dönemin olmazsa olmaz bir formülü olarak farklılık ötekinin inşa edilmesi üzerinde etkili olduğu ileri sürülebilmektedir. Zira, insanoğlu her ne kadar sosyal bir varlık olsa da diğer insanların varlığı, ilkel çağlardan itibaren her zaman en temel sorunlardan biri olmuştur. Bu sorunlar; felsefi, dini, siyasi ve sosyal olarak çözümlenmeye çalışılmıştır. Ancak tüm bu çözümleme girişimlerinde insanın kendi varlığı bir başkası üzerinden yapılandırılmıştır. Bu yapılandırılma, hem bizi hem de ötekini açıklayan ifadelerdir (Temizkan , 2011, s. 77). Bu ifadeler ayrımcılık politikalarını da inşa etmektedir.

Ayrımcılık ve ırkçılık politikaları, diğerlerinin/ötekilerinin farklılıklarına vurgu yapılarak onların aşağılık olduklarını ispatlama dışlamaya ya da yok etmeye dayalı bir politika izlemektedir. Ayrımcılık politikaları yüzünden insanlık tarihine bakıldığında, felaketlerle dolu bir yaşamın tarih sayfalarında yer aldığı görülmektedir. Ötekine karşı farklı muamele biçimleri içerisinde insanlığa en ağır tecrübeyi yaşatan durum ise ötekine yaşama hakkının tanınmamasıdır. En eski ayrımcılık görünümlerinden biri olan; ırkçılık, yabancı düşmanlığı, kölelik, soykırım, katliam, göç, tecavüz, aç bırakma gibi farklı dışlama pratikleriyle birlikte günümüze kadar gelen ayrımcılık insanlığın geleceğine yönelik tehdit unsurlarının en önemlileri arasında yer almıştır (Çelenk, 2010, s. 211-212). Bu ayrımcılık biçimleri, toplumun çeşitli korkularının bir dışavurum aracı dijital video 
oyunlarında da kullanılmaktadır. Böylece, dijital video oyunlarında, bir ötekinin inşa edildiği ileri sürülebilmektedir.

\section{Dijital Video Oyunlarında Öteki}

Video oyunlarının tarihsel gelişim sürecine bakıldığında beş ayrı aşama altında değerlendirilmesi mümkündür. Bu aşamalar şu şekildedir: (1) 1980 yılları öncesi erken gelişim aşaması, (2) 1980'li yılların ortası ile 1990'lı yılların ortasında yer alan büyüme aşaması, (3) 1990'lı yılların sonuna kadar yaşanan gelişme aşaması, (4) 2000-2005 yılları olgunlaşma aşaması ve (5) 2005'ten günümüze kadar olan ilerleme aşamasıdır. 2005 yılından günümüze kadar olan dönemde video oyunlarında yaşanan gelişme sonucunda bu sektörün bir pazar haline gelmesini de beraberinde getirmiștir. Bu doğrultuda, Dijital Oyun Sektörü Raporu'na göre; oyuncu kitlesinin zamanla artacağı da öngörülmektedir (Ankara Kalkınma Ajansı, 2019).

Teknolojinin gelişmesine bağlı olarak ortaya çıkan video oyunlarının erişilebilirliğinde ve çeşitliliğinde meydana gelen artışın sonucunda bir takım olumsuz düşünceler de beraberinde gelmektedir. Yani dijital video oyunlarında; ideolojik, kültürel, dinsel, ırksal vb. gibi çeşitli konularda bir yabancı/düşman yaratılarak ötekine yönelik içerikler sıkça üretilmektedir. Söz konusu bu durum, öteki kavramı ekseninde post apokaliptik bir dünyanın inşasını da meydana getirmektedir. Genel bir ifadeyle; video oyunları içerisinde oldukça yaygın bir bilimkurgu türü olan post apokaliptik dijitaal video oyunlarında, distopik bir dünya kurulmakta ve bu dünyada mutlaka yok edilmesi gereken bir öteki yaratılmaktadır.

Bu öteki, dijital video oyunlarında çeşitli şekillerde (zombi, canavar, mutant, siborg vs.) kendilerine yer bulmaktadır. Bilindiği üzere, bilimkurgu türlerinde en fazla kullanılan temalarından biri genetiğiyle oynanan veya nükleer etkilerden dolayı fizyolojik yapısı değişerek mutasyona uğrayan insan; üstün ırk ya da yabancıdır. Radyoaktif etkilerden dolayı genetiği bozulmuş olan insan figürü; post apokaliptik temalı sahnelerde genellikle saldırgan veya önceden sahip oldukları anatomik kodlara oranla sağlığı bozulmuş yeni bir ırkı düşündürtmektedir. Bunun yanında; dışlanan, ezilen, yanlış anlaşılan ve korkulan yeni bir sınıfsal modeli de ortaya çıkarmıştır.

Mutantlar, bazen devlet kanalları aracılığıyla yaratılan bir sınıf şeklinde de ortaya çıkmaktadır. Dijital ortamlarda; mutasyona uğramış insan türü genellikle olumsuz bir örnek olarak aktarılmaktadır. İkinci sınıf vatandaş muamelesiyle karşılaşan veya dışlanan, ötekileștirilen, köleleştirilen mutant figürü insan hükümdarlığı altına girmeyi reddetmekte veya biz'i yok etmeye çalışmaktadır. Yani; yaratılan mutantlar; insan egemenliğini yıkıp o sosyal yapının dışına çıkma veya o sosyal yapıyı tamamen yok etme eğilimine girmektedir (Yürür, 2015, s. 228-230).

Mutantların yanı sıra, bilim kurgu zemininde genellikle insan ve öteki olarak insan olmayan arasında nitelendirilen siborglar da yer almaktadır (Cornea , 2007, s. 276). Genellikle, öteki olarak nitelendirilen siborglar; yapay bir şekilde dönüşmüş ya da dönüştürülmüş insan vücudu olarak konumlandırılmaktadır. Bilim kurgu ortamlarında bu öteki yani zombi, canavarlar, mutantlar, siborglar vb. gibi varlıklar bilinçli veya bilinçsiz bir şekilde insanoğlunun kendisi tarafından yaratılmıştır. Özellikle, dijital ekranlarda post apokaliptik bir dünya tasviri yapılarak çeşitli varlıklar öteki olarak inşa edilmektedir. Zira, genellikle post apokaliptik temalı sahnelerde kurulan distopik bir dünyayla birlikte sunulan bu varlıklar; insanlığın karşısına çıkmış ve korku unsuru olarak da yerini almıștır (Sunato ve Karadon, 2013, s. 52-53). 
Bu doğrultuda, dijital video oyunlarında öteki bir korku unsuru olarak sunulmaktadır. Zira post apokaliptik dijital video oyunlarında oldukça fazla yer alan ötekiler (mutant, zombi, siborg vs); dışlanan, kabul edilmeyen, yok edilmeye çalışılan tehlikeli ve saldırgan varlıklardır. Genel bir ifadeyle, post apokaliptik dijital video oyunlarında; ayrımcılık, kin, nefret çerçevesinde bir öteki ve korku durumu da bir arada meydana getirmektedir. Dolayısıyla, ötekine yönelik bu korku durumu, post apokaliptik temalı sanal bir dünyada yeniden inșa edilmektedir.

\section{Dijital Video Oyunlarındaki Post Apokaliptik Dünya'da Korku ve Öteki}

Video oyunlarını gerçek hayatla tamamen soyutlamak mümkün değildir. Zira, video oyunları kısmen de olsa bir gerçekliği bünyesinde taşımaktadır. Çünkü video oyunlarının sahnelerinde yer alan olaylar gerçek hayattaki kuralları, kurmaca bir dünyanın arasına sıkıștırmıştır (Jull, 2005). Zira bilimkurgu insanlığın en kötü korkularının yansıması olarak tasarlanmaktadır. Bu çerçevede, video oyunlarındaki göstergeler, gerçekliğe dair izleri de bünyesinde taşıdığı ileri sürülebilmektedir. Bu bakımdan, gerçek yaşamdan hareketle post apokaliptik dijital video oyunlarında korku ve öteki konusunu da düşünmek gerekmektedir.

Bilindiği üzere, bilimsel hakikatin araştırılması esnasında, insanoğlu doğaya egemen olmak amacıyla büyük ilerlemelerle karşı karşıya kalmıştır. Akıl Çağı'ndaki bu ilerlemeler insanoğlunun yaşamını kolaylaştırmak ve doğaya egemen olmak fikrini en üst seviyede tutmuştur. Ancak, bu ilerlemeler bir yıkım sürecini de beraberinde getirmiștir. Zira, savaş, yıkım, ölüm vb. gibi unsurların temelinde insanoğlunun kendi eliyle yarattığı teknolojinin etkisi de oldukça büyüktür. Böylece, teknolojik ilerlemeler, insanoğlunun hayatını kolaylaștırdığı; ancak belli başlı sorunları da beraberinde getirdiği söylenebilmektedir (Yürür, 2015, s. 62). Genel bir anlatımla; 21. yüzyıla gelindiğinde, insan ve doğa kavramları üzerinden felsefi bir takım sorgulamalar söz konusu olmuştur. Bilimsel ilerlemeler sonucunda, dünyanın ve doğanın yok olacağı düşüncesi de beraberinde gelmiştir. Bu durum Frankfurt Okulu'nun aydınlanmaya yönelttiği eleştirinin içerisinde de anlamlı bir hale gelmektedir. Bu çerçevede, bilimsel ilerlemelerle meydana gelen gelişmeler, zamanla olumsuz sonuçları da doğurduğu iddia edilmektedir (Adorno \& Horkheimer , 2016). Bu doğrultuda, teknolojik ilerlemelerin iyi mi yoksa kötü mü olduğuna dair tartışmalar da söz konusu olmuştur.

Teknolojinin kötü tarafına dikkat çekenlerin ortak noktasıysa; teknolojinin insanoğlunun yaşadığı ortamı yok edebilecek bir güce sahip olmasıdır. Bu çerçevede, teknolojik ilerlemelerin kötü tarafına dikkat çekmek amacıyla İkinci Dünya Savaşı ve sonrası da örnek gösterilebilmektedir. İkinci Dünya Savaşı'ndan sonra sıcak çatışma ortamının sona ermesiyle birlikte, uygarlık fikri yeniden sorgulanmaya başlanmıștır. Örneğin, atom bombalarıla yayılan radyasyon ve bu radyasyonun uzun süreli yan etkileri, toplumsal kıyametin veya kitlesel yıkımın uzak olmadığına dair sinyalleri yakmıștır. Yani, insan eliyle yaratılan medeniyet, kısa bir süre içerisinde yine insan eliyle yaratılan silahlarla yok olma tehlikesiyle karşı karşıya kalmıştır (Yürür, 2015, s. 222). Diğer bir anlatımla; eleştirel teorisyenlerin de belirttiği gibi; 17. yüzyıldan itibaren hayatın merkezine konulan ütopyalar eşsiz bir amaç olsa da 20. yüzyılın başlarında ütopyaların aksine distopyaların açığa çıktığı görülmüştür (Altınkaya, 2016, s. 87).

Bu durum, bilimkurgu sahnelerine de yansımış ve bu sahneler gerçek yaşamın toplumsal sorunlarını açığa çıkarmaya da başlamıştır. Yani, Soğuk Savaş’ın etkisiyle birlikte 1970’li yıllardan itibaren, bilimkurgu sineması artık bakış açısını gerçekliğe yöneltmiştir 
(Sönmeyen, 2016, s. 98). Diğer bir deyişle; dijital ortamlardaki bilimkurgu türleri, zamansal ve uzamsal düzlemde geleceğe yönelik bir dünya sunmaktadır. Aynı zamanda bu dünyada insan ilişkilerini betimleyen bir anlatı yapısını ortaya koymaktadır. Bunu yaparken de bazen eleştirel bir bakış açısıyla distopik, bazen de eleştirel bakıștan uzak bir perspektiften ütopik bir temsil içermektedir. Fakat unutulmamalıdır ki; bilimkurgu sahneleri hiçbir zaman yaşanan dünyadan tamamen kopuk değildir (Göker ve Keskin, 2015, s. 430). Ancak, bu dijital sahnelerde nesnelliğin bir önemi yoktur. Asıl önemli olan, bir felaket senaryosunun uygun olmasıdır (Baudrillard, 2010, s. 42).

2000'li yıllardan itibaren, distopik sahnelerin başat temaları arasında yer almayı başaran felaket senaryoları; distopik temalar eşliğinde post apokaliptik bir dünyayı inşa ederek sanal ortamlarda sıklıkla yer almıştır. Bu post apokaliptik sahneler; felaketten ayakta kalan insan grubunu da tanımlayarak bir ötekileştirme mekanizmasını da ortaya çıkarmaktadır (Roloff ve Seeblen, 1995, s. 254). Zira, bu sahnelerdeki biz'im hayatta kalma çabası olarak şekillenen distopik temalar; dış uzaydan gelen yaratıkların, zombilerin, canavarların istilası vb. gibi konular üzerinden işlenmektedir.

$\mathrm{Bu}$ yaratıkların inşa edilmesinde, teknolojik ilerlemelerin de etkili olduğu söylenebilir. Burada üzerinde durulan temel noktalardan birisi de, teknolojinin kontrolünü elinde tutan grupların; nüfusun geri kalanı üzerinde ölçüsüz bir şekilde bu teknolojik aygıtları kullanmasıdır (Sönmeyen, 2016, s. 6). Söz konusu bu durum, toplumsal ayrışma ve ötekileștirme politikalarını da beraberinde getirmiștir. Zira, post apokaliptik bir yașam alanında, Tanrı'nın hakimiyeti altında olan yeryüzünün revizyona uğraması sonucunda dünyaya egemen olan güç yine insanın kendisi olup tüm yıkıma karşılık yeniden inşa sürecini de insanoğlunun kendisi yönlendirmektedir (Yürür, 2015, s. 90). Burada inşa sürecinde ötekine yönelik alınacak tavrı da insanoğlunun kendisi belirlemektedir. Diğer bir ifadeyle; gerçek hayatta yaşanan çeşitli durumlar karşısında insanoğlunun gelecek yaşama yönelik merakı artması sonucunda distopik bir dünyayla karşı karşıya kalınacağının farkına varmıștır. Dolayısıyla, insanoğlunun bu korkusu dijital ortamlarda da distopik bir dünya inşa etmiş yine post apokaliptik dönemdeki bu karanlık dünyada bir düşman yaratmayı unutmamıştır. Bu düşman öteki olarak tanımlanmış ve ötekinden uzak kalınması veya yok edilmesi gerekliliği hayati bir önemde sunulmuştur. Burada, öteki ile biz arasında heterotopik bir alan da oluşturularak, mekânsal ayrışma temelli bir heterotopya inșa edilmiştir.

\section{Post Apokaliptik Dijital Video Oyunlarında Mekânsal Ayrışma: Heterotopya}

İlkel çağlardan itibaren post apokaliptik döneme kadar, insanoğlunun sürekli savaşması gerektiği bir öteki yaratıldığı bilinmektedir. Bu varlıklar, insanların oturduğu bölgeye gelerek onları rahatsız eden, olması gereken yerde olmayan, yabancı, yerli bireylerde korku duygusunu uyandıran varlıklar olarak video oyunlarında kendine yer bulmuștur. $\mathrm{Bu}$ doğrultuda, post apokaliptik temalı video oyunlarında, oldukça sık işlenen konular arasında yer alan öteki heterotopik bir alanın inşa edilmesi sürecinin doğal bir parçası olarak sunulmaktadır.

Burada öncelikle heterotopya kavramına bir açıklık getirmek gerekmektedir. Latince bir kelime olan heterotopya tıbbi bir terim olup: bir organın ya da oluşumun olması gereken yerde olmayıp, başka bir yerde bulunması șeklinde tanımlanmaktadır (Sağlık sözlügü̈, 2020). Heterotopya kavramını Foucault toplumsal yaşam alanına da uyarlamıştır. Ona göre; ilkel ve modern dönemlere göre farklı heterotopya biçimleri söz konusudur. İlkel toplumlarda kriz heterotopyaları şeklinde bir heterotopya biçimi vardır. Burası, 
ayrılmış, ayrıcalıklı, kutsal ya da yasak yerlerdir. Ancak, Foucault, çağdaş toplumlarda kriz heterotopyaların yok olmaya yüz tuttuğunu ve günümüzde sapma olarak nitelendirilebilecek heterotopyaların ortaya çıktığını belirtir. Bu yerler; tımarhaneler, hapishaneler, hastaneler, okullar vb. gibi ayrılmış alanlardır (Foucault, 2005, s. 295-298).

Bilindiği üzere; birey sahip olduğuna inandı̆̆ı, mekânı ya kendisi kapanmak veya ötekini kapatmak için kullanmaktadır. Bu kapanma/kapatma pratikleri; insan düşüncesinde ve eylemlerinde kapsayıcı bir rol üstlenmektedir. İnsanoğlu, kapandığı mekânda kendisini koruma altında almak amacıyla bu mekânı ötekilere yasaklamaktadır (Nakıboğlu , 2015, s. 3). Ya da ötekini başka bir mekâna kapatarak kontrol ve denetim altına almaya çalışmaktadır. Genel bir anlatımla; biz ve öteki arasında heterotopik bir alan inşa edilerek, bir düşman metaforuyla sunulan öteki ile yaşam alanlarının keskin sınırları çizilmektedir.

Post apokaliptik dijital video oyunlarında, distopik bir geleceğin tasviriyle inşa edilen öteki ve biz arasında mekânsal anlamda keskin sınırlar da çizilmektedir. Bu keskin sınırlar, bir heterotopya biçimini oluşturarak biz ve öteki arasındaki yaşam alanlarını tamamıyla ayırmıştır. Böylece, ötekinin bu yaşam alanına girmesine asla müsaade edilmemeye çalışılmış ya da öteki heterotopik bir alana sıkıștırılmıştır. Biz kendisini koruma altına almak için heterotopik alana sıkışmaktadır. Öteki ise, biz’e yönelik tehlikesinden uzak durmak, onları disiplin ve gözetim altına almak amacıyla heterotopik bir alana sıkıştırılmaktadır. Zira, post apokaliptik dijital video oyunlarında düşman metaforuyla sunulan yaratıklar/ötekiler; tehlikeli, zararlı, korkunç, istilacı, vahşi bir canavar olarak tasarlanmaktadır. Bu bakımdan, heterotopya biz ve öteki arasındaki ayrıșmayı da adil kılmaktadır. Dolayısıyla, video oyunlarında, öteki ve biz arasında bir heterotopyanın inşa edilmesinin kaçınılmaz olduğu ileri sürülebilmektedir.

\section{Yöntem}

\section{Araştırma Modeli}

Nitel yöntemle hareket eden bu çalışma; durum çalışması modeliyle desenlenmiştir. Bu araștırma deseni, bir veya birkaç durumu kendi sınırları içerisinde bütüncül bir biçimde analiz etmektedir. Durum çalışması deseninde amaç ise; belirli bir duruma ilişkin sonuçlar ortaya koymaktır (Yıldırım ve Şimşek, 2013, s. 83-85).

\section{Araştırma Soruları}

Bu çalışmada, aşağıdaki araştırma sorularına cevap aranacaktır.

1. Post apokaliptik dijital video oyunlarında öteki nasıl sunulmaktadır?

2. Post apokaliptik dijital video oyunlarında ötekini yok etme nasıl meşrulaștırılmaktadır?

3. Post apokaliptik dijital video oyunlarındaki distopik bir dünyada, heterotopik bir alan var mıdır? Varsa, biz ve ötekiler çerçevesinde bu heterotopik alan nasıl sunulmaktadır?

4. Post apokaliptik dijital video oyunlarında, teknoloji ötekine karşı nasıl sunulmaktadır?

\section{Çalışma Kümesi}

Çalışma kümesini, 2000 sonrasındaki post apokaliptik dijital video oyunları oluşturmaktadır. Çalışma kapsamında elde edilen video oyunlarının sınırlılığı ise çeşitli aşamalardan oluşmuştur. Hangi oyunun seçileceğini belirlemek için çalışmanın amacına 
yönelik olarak Nitel Araştırma örneklem tekniklerinden ölçüt örneklem kullanılmıştır. Bu ölçütler şu şekildedir:

(1) Oyunun kıyamet sonrası temasının yoğun olmasıyla birlikte insanlığın o zamandaki korku durumuna ilişkin bilgiler içermesi. (2) Bir öteki olarak bir düşmanın inşa edilmesi ve bu ötekinin yaşamak için yok edilmesi zorunluluğunun olması. (3) Teknolojik ilerlemelerden (nükleer felaket, küresel ısınma vb. gibi) dolayı insanlığın sonunun gelmesi. (4) Hayatta kalan insanların yaşamak için savaş teknolojilerine muhtaç olmaları; ötekilerin ise teknolojiden yoksun ilkel yaratıklar olmaları. (5) Yeryüzünde yaşamın mümkün olmaması ve insanların yaşamak için bir heterotopik bir alan oluşturarak bu heterotopik alana sığınmaları.

Belirlenen ölçütlere uygun olan post apokaliptik dijital video oyunlarıyla sınırlandırılan bu çalışmada, Metro 2033 adlı video oyunu çalışmaya dâhil edilmiştir.

\section{Verilerin Analizi}

Elde edilen veriler; göstergebilimsel çözümleme yöntemiyle çözümlenecektir. Göstergebilimsel çözümleme yönteminin kullanılmasının temel amacı ise; verilerin elde edilmesinde en uygun çözümleme tekniği olduğunun düşünülmesidir. Bu noktadan hareketle; kültürel, sosyal, tarihsel ve ekonomik boyutlar da göz önünde bulundurularak Barthes'in kuramı dikkate alınıp veriler düzanlam ve yananlam boyutuyla çözümlenecektir.

Barthes, göstergelerle donanmıș dünyadaki nesnelerin; toplumsal, ahlaksal ve ideolojik açıdan değerler içerdiğini belirtmektedir. $\mathrm{Bu}$ içerikleri çözümlemeyi amaç edinen sistematik düşünceyi ise, göstergebilim olarak adlandırmıştır. Ayrıca, Barthes, düz anlam göstergenin neyi temsil ettiğini; yan anlam ise bir göstergenin nasıl temsil edildiği üzerine kurulu olduğunu ifade etmiştir (Barthes, 2018).

Bu bakımdan, göstergede ilk görülen yani yüzeysel anlam düzanlamsal boyutuyla ele alınacaktır. Bunun yanı sıra göstergeler; ideolojik, toplumsal ve kültürel anlamdaki izlerinin açığa çıkarılması amacıyla, yananlamsal boyutuyla ele alınacaktır. Zira, göstergelerin her zaman mutlaka bir yananlamı bulunmaktadır (Sığırcı, 2017, s. 76).

Ayrıca, çalışmada temel karşıtlıklar da açığa çıkarılacaktır. Zira, temel karşıtlıklar tespit edilerek bunlar üzerinde kurulan anlamlar, öteki bağlamında detaylı bir şekilde açığa çıkarılmasını sağlayacaktır.

\section{Düzanlam ve Yananlam Gösterenleri}

Herhangi bir göstergenin açık bir şekilde görülen tarafı olarak düz anlam; kim ya da ne şeklinde sorulan sorulara cevap verebilmektedir. Bu bakımdan, çalışmada Metro 2033 adlı post apokaliptik dijital video oyununun düzanlam gösterenlerine dair bilgiler genel hatlarıla sunulacaktır.

Yananlamsal boyutta ise; eldeki veriler öteki bağlamında derinlemesine incelenecektir. Burada, göstergenin kim ya da ne olduğu değil nasıl olduğu üzerinde durulacaktır. Bu çerçevede, Metro 2033 adlı oyunda elde edilen çeşitli göstergelerin derin yapıdaki anlamları da açı̆̆a çıkarılacaktır.

\section{Metro 2033 Adlı Dijital video Oyunu Hakkında}

Oyun başladığında Artyom, Hunter adındaki askerden metronun Karaderililer ${ }^{2}$ olarak nitelendirilen yaratıklar tarafından tehdit edildiğini öğrenir. Bundan dolayı, Hunter tek başına tünele çıkar. Ancak, Hunter tünele çıkmadan önce Artyom'a eğer geri dönmezse 
metronun merkezi olan Polis adlı istasyona gitmesi gerektiğini belirtir. Daha sonra, Hunter geri dönmez. Böylece, Artyom metro tünellerinde yola koyulur, bu yolculuk boyunca kimi zaman çeşitli hayaller görür. Artyom, Sovyetler ve Naziler tarafından işgale uğramış ve mutantlar tarafından istila edilmiş bir bölgeden de geçmek zorunda kalır. Daha sonra, Artyum Polis'teyken kendine yardım edeceğini düşündügü Miller ${ }^{3}$ ile tanışır. Daha sonrasındaysa, Artyom, Miller ve diğer Rangerlar füze kumanda merkezini devreye sokmaya çalışırlar. Sonrasındaysa, Artyom, yakındaki bir binaya rehber lazer sistemi kurar. Lazer sistemi kurulduktan sonra Artyom, Kara Derililer'in neden olduğu bir halisünasyon görür. Bu halisünasyon sonucunda oyuncunun yaptığı seçimlere göre oyun iki türlü biter.

Normal/kötü sonda, Artyom füzeleri ateşler ve Karaderililer yok edilir. Ancak, alternatif/ iyi son ise Karaderililer'in bu halisünasyonlarla barışçıl bir çözüm istediklerini düşündürerek Artyom'a rehber lazer cihazını yok etme fırsatını verir. Hangi sonun seçileceğiyse; oyunu oynarken yapılan istatistiklere göre belirlenir. Alternatif sona hak kazanıldıysa silah ile rehber lazeri vurmak veya füzelerin ateşlenmesini beklemek arasında bir seçim yapılabilir. Ancak, yeterince moral puanı yoksa halüsinasyondan çok geç uyanılır ve lazeri vurma firsatı oyuncuya verilmez (https://tr.wikipedia.org/wiki/ Metro_2033_(video_oyunu), 2020).

Genel anlatımla, Artyom adlı karakterin bakış açısına göre oynanan oyunun çoğu, kıyamet sonrası Moskova'daki metro sisteminde geçmektedir. Fakat bazı görevler oyuncuları yeryüzüne çıkarır. Oyunda kullanması için bazen hayali bazense gerçek silahlarla örtüşen birçok ateşli silah çeşidi bulunmaktadır. Çatışmalarsa mutantlara veya düşman insanlara karşı gerçekleşmektedir. Mutantlar silahsız ve insanlara daha çok sürüler halinde fiziksel saldırı yaparken, karşı grup insanlar oyuncunun sahip olduğu ateşli silahlarla saldırabilir.

\section{Bulgular ve Yorum}
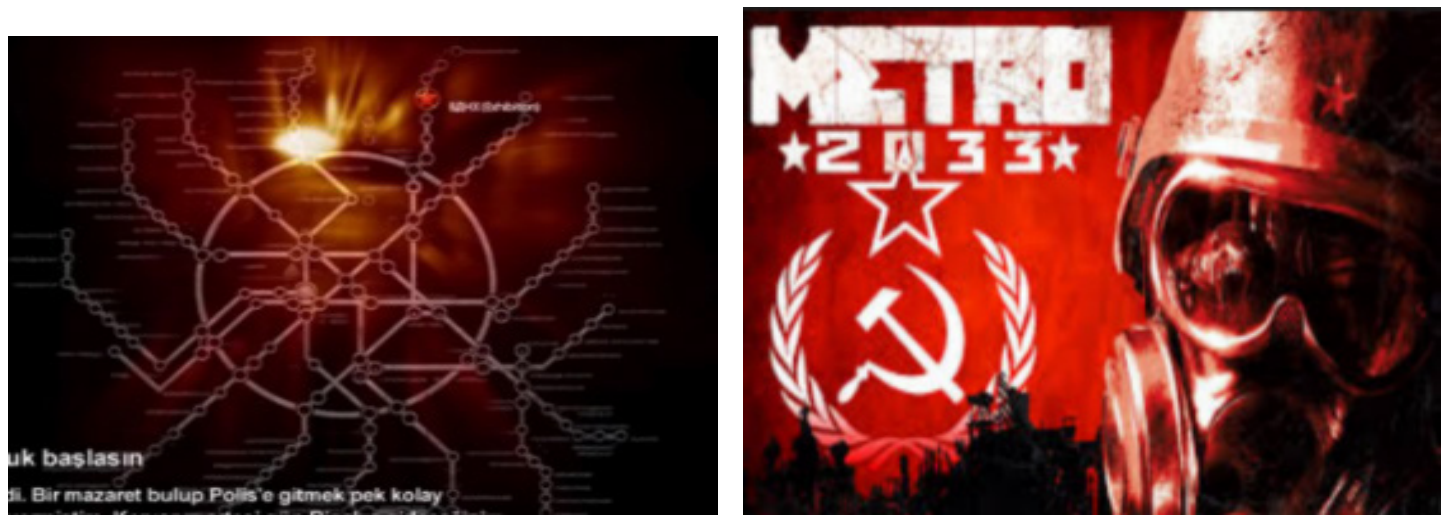

Görsel 1: Video Oyunundaki İdeolojik Mesajların Göstergebilimsel Çözümlemesi

\begin{tabular}{|l|l|}
\hline 1. RENK & Kırmızı (Güç, Kan, Ölüm, Şiddet, Vahşet, Nefret) \\
\hline 2. GÖSTERGE & Görsel 1 \\
\hline 3. GÖSTEREN & Kroki/ Işık /Yıldız/ Kask/ Logo \\
\hline 4. GÖSTERiLEN & - \\
\hline 4.1. Düzanlam & $\begin{array}{l}\text { Oyundaki Metro'ya ait kroki ve bir askerin kask kullandığı gösterilmektedir. } \\
\text { Askerin arkasında ise bir simge bulunmaktadır. }\end{array}$ \\
\hline 4.2. Yananlam & $\begin{array}{l}\text { Kroki, gerçek Moskova Metrosu'nu hatırlatmaktadır. Simge ise; Sovyetleri } \\
\text { Birliği'ni temsil etmektedir. Kaskın kullanıması ise, nükleer felaketlerin } \\
\text { oksijen almak gibi yaşamsal unsurları yok ettiğini göstermektedir. }\end{array}$ \\
\hline
\end{tabular}


Bir görüntüye yüklenen anlam, bazen toplumsal bazen de bireysel koşullanmaya bağlı olarak gerçekleşebilmektedir (Akerson, 2016, s. 216). Bu doğrultuda, içinde bulunulan durum bir görüntüye anlam yükleme durumuna etki edebilmektedir. Görsel 1'deki görüntülerde; SSCB’ne dair çeşitli ideolojik mesajların iletildiği görülmektedir.

Bu oyunda SSCB'nin bayrağının da kullanılması (örnek soldaki resim); post apokaliptik bir dünyada egemen tek gücün SSCB olacağı ve SSCB'nin dünyayı egemenliği altına alacağı, diğerlerini dışlayacağı (ötekileştirileceği) bir dünyaya dair mesajlar sunulduğu söylenebilir. Dolayısıyla, Metro 2033 adlı video oyununun derin bir ideolojik anlamlara sahip olduğunu ifade etmekte mümkündür.

Görsellerde yer alan renk öğesine bakıldığında ise; kırmızının ağırlıklı bir şekilde kullanıldığı görülmektedir. Kırmızı; "canlılık, mutluluk, girişkenlik, dışa dönüklük, irade, güç, cinsel güç, kızgınlık, hırs (...) sevgi ve nefret gibi iki zıt duyguyu da bünyesinde taşımaktadır." (Kırık, 2013, s. 73-74). Bu bakımdan, kullanılan kırmızı tonlarının güç ve nefret ekseninde sunulduğu söylenebilir.

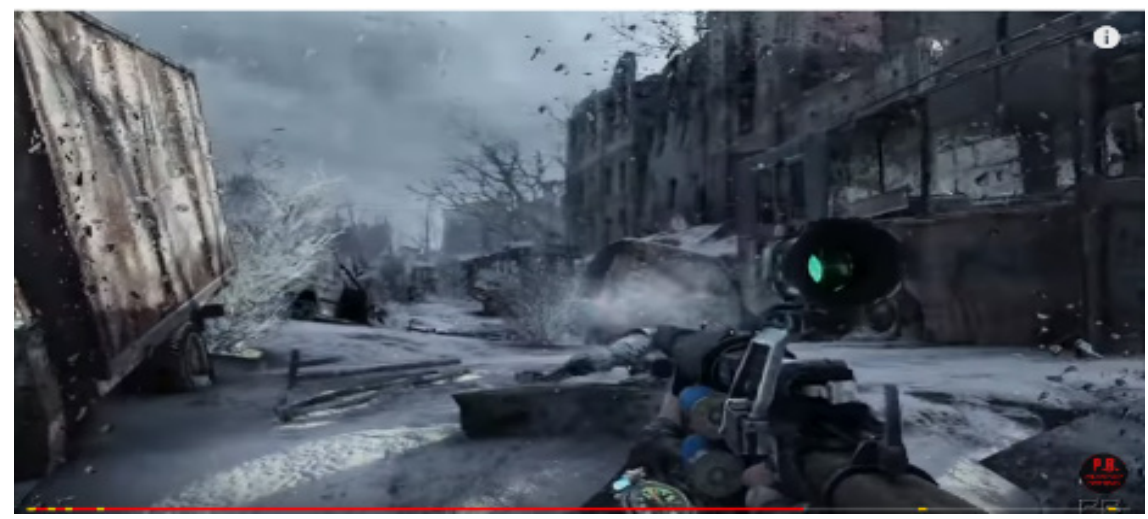

Görsel 2: Video Oyunundaki Yeryüzünün Görünümüne Dair Göstergebilimsel Bir Çözümleme

\begin{tabular}{|l|l|}
\hline 1. RENK & Gri tonları (Korku, gerilim, bunalım, depresyon) \\
\hline 2. GÖSTERGE & Görsel 2 \\
\hline 3. GÖSTEREN & Silah/ Harabe olmuş bir sokak \\
\hline 4. GÖSTERiLEN & - \\
\hline 4.1. Düzanlam & Savaşın etkisiyle harabe olmuş bir sokakta asker, tetikte beklemektedir. \\
\hline 4.2. Yananlam & $\begin{array}{l}\text { Hazır tetikte beklenilmesiyle; ötekilerin yaşamasına fırsat verilmemekte ve ötekilere yönelik } \\
\text { yok etme biçimi meşrulaştırımaktadır. Ayrıca, yıkık dökük bir sokağın gösterilmesi ise } \\
\text { düzenin bozulduğunu ve modern hayatın alt üst olduğuna yönelik izleri taşımaktadır. }\end{array}$ \\
\hline
\end{tabular}

Görsel 2'deki göstergede, post apokaliptik bir dünyada yeryüzünde normal bir yaşamın mümkün olmadığı ve yeryüzünün distopik bir alan olacağına dair mesajların iletildiği görülmektedir. Yeryüzünde düzenin bozularak felaketlerin yaşanacağl ve böyle bir dünyada bile yine düşmanların olacağına dair mesajlar yananlamsal bir biçimde sunulmaktadır. Zira yeryüzünde yaşamın mümkün olmamasına rağmen bir düşman algısı yaratılarak ötekilerin yok edilmesi zorunlu kılınmaktadır. Burada öldürmeye veyahut yok etmeye yarayan teknolojik araçların kullanılması (mermi, silah vb.) insanoğlunun post apokaliptik bir dünyada teknolojiye bağımlı olacağı ve bu teknolojileri kullanmayanların çeșitli yaratıklara (ötekilere) kurban olacağına dair mesajları da gösterdiği ileri sürülebilmektedir. Yani, bu düşmanların (ötekilerin) savaş teknolojileriyle (mermi, silah vb.) kontrol altına alınıp yok edilmesi gerektiği de vurgulanmaktadır. Diğer bir anlatımla, gözetim mekanizmasıyla ötekiler sürekli kontrol altına alınması gerekmektedir. 
Eski dönemlerdeki ötekinin gözden uzak gayesiyle şekillenen sistemin aksine, ötekini; panoptikon gibi sürekli gözetim altında tutmak ve göz önünde bulundurmak esasına dayanan başka bir sistem ortaya çıkmıştır. Burada göz önünde bulunduran, ben ya da biz olmaktadır. Ben'in sürekli gözetlediği (Nakıboğlu , 2015, s. 388) bir dünyada ötekine yönelik olumsuz çağrışımlar da yapılmaktadır. Çünkü ötekiler hiçbir zaman boş bırakmaya gelmeyen; yabani, ilkel, kötü ve tehlikeli varlıklar olarak video oyununda temsil edilmektedirler.

Görsel 2'de yoğun bir şekilde olarak kullanılan renk ise gridir. Gri rengi; "kimi zaman sıkıntılı duyguları ve olumsuzlukları yansitabilmektedir." (Kırık, 2013, s. 77). Dolayısıyla, görselde kullanılan renge anlam yüklemek de mümkündür.
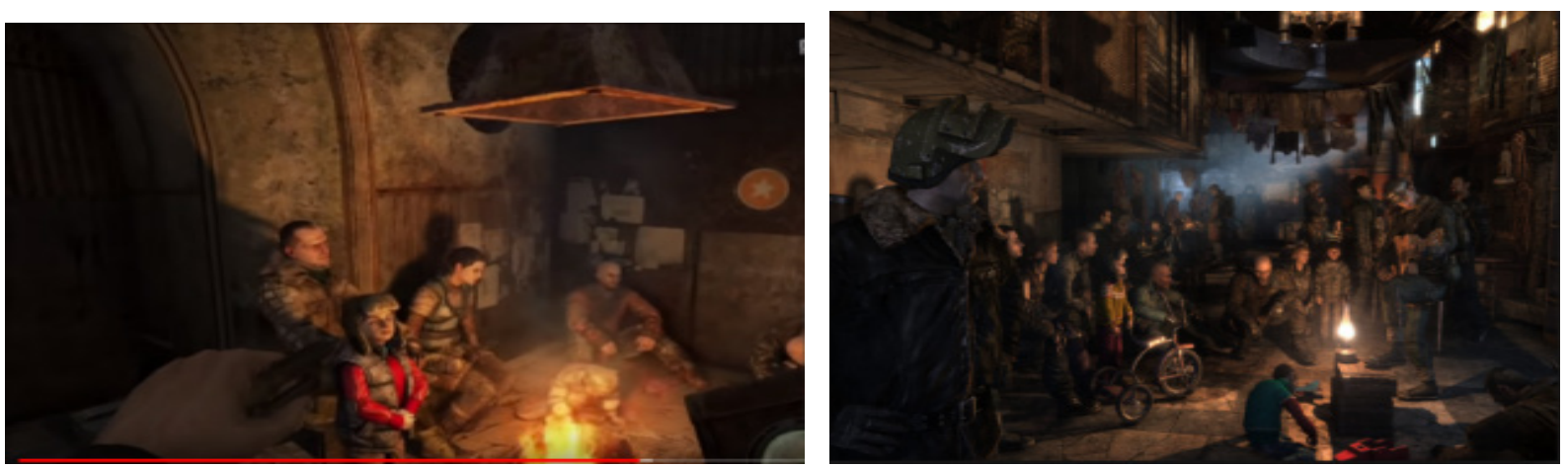

Görsel 3: Video Oyununda İnsan Topluluğu ve Heterotopik

Bir Alana Dair Göstergebilimsel Çözümleme

\begin{tabular}{|l|l|}
\hline 1. RENK & Siyah renk tonları (korku, hüzün, gerilim, huzursuzluk) \\
\hline 2. GÖSTERGE & Görsel 3 \\
\hline 3. GÖSTEREN & Asker/ Erkek/ Kadın/ Çocuk/Ateş / Bisiklet/Gitar \\
\hline 4. GÖSTERiLEN & - \\
\hline 4.1. Düzanlam & $\begin{array}{l}\text { Heterotopik bir alanda ilkel hayat süren insan grubu, ateşin başında beklemektedir. Diğer } \\
\text { resimdeki halk ise gitar çalan kişi etrafında oturup günlük aktiviteleri sınırlı bir şekilde } \\
\text { gerçekleştirmektedir. Erkek bir asker ise, bu topluluğu korumak amacıyla beklemektedir. }\end{array}$ \\
\hline 4.2. Yananlam & $\begin{array}{l}\text { Post apokaliptik bir dünyada ötekilerden kaçış, halkı ilkel bir hayata geri götürmektedir. } \\
\text { Koruma, güvenlik ise erkek güç tarafından sağlanmaktadır. Ötekiler ise yaşanılan } \\
\text { yere girmesine asla müsaade edilmeyen tehlikeli yaratıklar olarak bilindiğinden dolayı } \\
\text { sürekli gözetim altında tutulması gerektiğine dair mesajlar da inşa edilmektedir. }\end{array}$ \\
\hline
\end{tabular}

Görsel 3'teki göstergelere bakıldığında; küçük insan toplulukları görülmektedir. Video oyunundaki bu göstergeler; ötekinden kaçışı meşru kılmaktadır. Diğer bir ifadeyle; yaratıklar yani ötekiler tehlikeli ve kötüdür. Onlardan kaçmak gereklidir. Zira, insanların yaşaması gereken modern bir yeryüzünden ziyade ilkel bir heterotopik alan oluşturularak insanoğlunun bir alana sıkışmaları bir heteropyanın inşa edilmesini de normal kılmaktadır. Zira, ötekilerin tehlikeli olduğu ve biz'in koruma altında olması için onlardan/ ötekilerden saklanılması, kaçınılması gerektiği yananlamsal bir şekilde gösterilmektedir. Ayrıca ötekiler; biz'lerin yaşadığı yere gelmemesi için bu heterotopik alanın askeri güçler tarafından (örneğin; yukarıda tetikte duran asker resmi) sürekli kontrol altına alınması ve gözetilmesinin gerekliliği de sunulmaktadır. genel bir anlatımla; video oyununda, hayatta kalan insanların olması gereken yerde olmayıp başka yerlere sığınmak zorunda bir heterotopyanın oluşturulduğunu göstermektedir.

İnsanoğlunun, heterotopik bir alan kurarak; olması gereken yerde olmaması ötekilerden kaçışın doğal bir parçası olmakta ve bu kaçış adil bir ayırma stratejisini de beraberinde 
getirmektedir. Böylece, Görsel 3'te de görüleceği üzere; ötekiler, tehlikelidir dolayısıyla onlardan uzak durmak gerekmektedir şeklinde bir algı oluşturulmaktadır. Post apokaliptik bir dünyada ötekilerden kaçışın dayatmış olduğu bu mekânsal ayrışma biz'lerin de olması gerektiği yerde olmamasına neden olduğunu göstermektedir. Diğer bir ifadeyle; insanoğlu için yeryüzünün modern biçimi sonra ermiş ve insanoğlu olması gereken modern evlerinde değil heterotopik yani bambaşka bir alanda yaşamak zorunda kalmıştır. Bu doğrultuda, ötekilerden kaçış biz'leri heterotopik bir alana sürükleyeceği yananlamsal bir biçimde ortaya çıkarılmaktadır.

Görsel 3'te siyah renk tonlarının belirgin olarak kullanıldığı görülmektedir. Siyah rengi “gücü, tutkuyu, resmiyeti, soyluluğu ve otoriteyi simgelemektedir. (...) keder, ölüm ve matem anlamlarına gelmektedir. Bununla birlikte; fesatlık, garez, kötü niyet ve karamsarlığı da çağrıştırabilmektedir. Kısacası insanlar üzerinde olumsuz etkiler uyandırabilmektedir (...) Kötülügün, korkuların, stresli anların ve kargaşaların meydana gelişini siyah simgelemektedir (...) Siyah şiddetin de rengidir." (Kırık, 2013). Dolayısıyla burada kullanılan renge de göstergebilimsel açıdan bir anlam yüklemek olağandır. Ayrıca, yüksek açılı bir çekimin de kullanılması bu halk kitlesinin o anki çaresizliğini de yananlamsal bir biçimde göstermektedir.

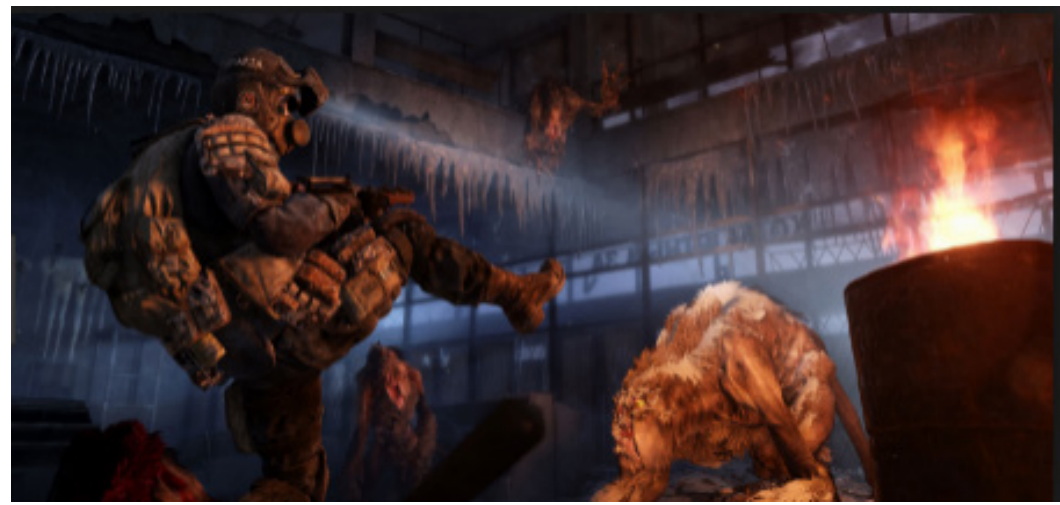

Görsel 4: Video Oyunundaki Öteki'nin İtaatini Gösteren Bir Göstergenin Göstergebilimsel Cözümlemesi

\begin{tabular}{|l|l|}
\hline 1. RENK & Mavi renk tonları (Sakinlik, özgürlük, sessizlik) \\
\hline 2. GÖSTERGE & Görsel 4 \\
\hline 3. GÖSTEREN & İnsan/ İnsan olmayan \\
\hline 4. GÖSTERiLEN & - \\
\hline 4.1. Düzanlam & Bir asker yerde diz çöken yaratığa (ötekine) tekme atarak şiddet uygulamaktadır. \\
\hline 4.2. Yananlam & $\begin{array}{l}\text { Askerin güçlü olduğu gösterilmekte ve ötekilere yönelik şiddet } \\
\text { meşrulaştırımaktadır. Ayrıca, öteki olarak nitelendirilen yaratığın diz } \\
\text { çökmesi ötekilerin ilkelliğini ve acizliğini de göstermektedir. }\end{array}$ \\
\hline
\end{tabular}

Yıkık ve harabe olmuş bir yerde askerin ötekine yönelik şiddet uyguladığı bu göstergede askerlerin güçlülüğü; yaratıkların (ötekiler) ise güçsüzlüğü, acizliği vurgulanmaktadır. Zira; diz çökmek, yer öpmek vb. gibi ayakla ilgili ifadeler karşı tarafın gücünü ve otoritesini kabul etmek anlamında kullanıldığı bilinmektedir (Çetinkaya, 2015, s. 88). Ayrıca, alt açılı çekim, askerin egemen güç olarak sunulduğunu göstermektedir.

Genel bir ifadeyle; askerin ayağını kaldırarak yaratığa (ötekine) şiddet uygulaması hem ötekilere yönelik şiddeti meşrulaştırmakta hem de bu asker karakterinin güçlü olduğunu göstermektedir. Bir diğer ifadeyle; ötekiler her ne kadar biz'i tedirgin eden tehlikeli yaratıklar olsalar da diğer yandan biz'e diz çökecek kadar da aciz varlıklardır. Çünkü 
biz daha güçlüyüz şeklindeki anlamları da taşıdığı söylenebilmektedir. Bu göstergede yoğun olarak kullanılan renk ise mavi rengidir. "Mavi, insanları asabi zamanlarında sakinleştirmekte ve aynı zamanda özgürlük anlamı taşımaktadır." (Kırık, 2013, s. 75). Dolayısıyla, ötekilerin güçsüzlüğünü gösteren bu sahnede mavi renginin daha fazla olmasına bir anlam yüklemek mümkündür.

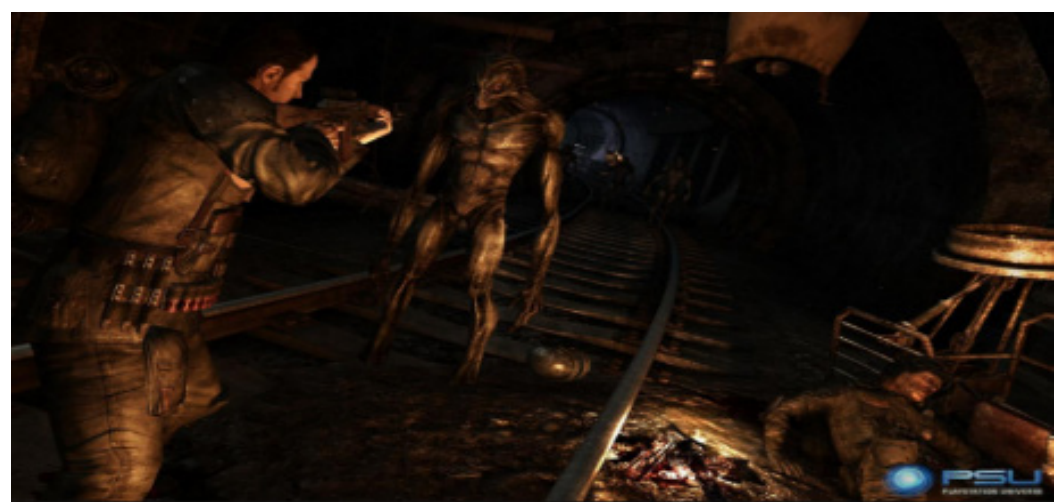

Görsel 5: Video Oyunundaki Öteki'nin Teslimiyetine Dair Bir Göstergenin Göstergebilimsel Çözümlemesi

\begin{tabular}{|l|l|}
\hline 1. RENK & Siyah renk tonları (korku, hüzün, gerilim) \\
\hline 2. GÖSTERGE & Görsel 5 \\
\hline 3. GÖSTEREN & İnsan/İnsan olmayan /Tünel/ Ceset \\
\hline 4. GÖSTERILEN & - \\
\hline 4.1. Düzanlam & $\begin{array}{l}\text { Elinde herhangi bir savaş aleti bulmayan bir yaratıkla elinde } \\
\text { silah bulunan bir asker karşı karşıya durmaktadır. }\end{array}$ \\
\hline 4.2. Yananlam & $\begin{array}{l}\text { Bir asker, ötekini elindeki silahla yok etmeye çalışmaktadır. Öteki her ne kadar bedensel } \\
\text { olarak güçlü bir yapadıa (kaslı) sunulsa da teknolojik imkânlardan yoksundur. Ancak } \\
\text { yerde bir asker cesedinin olması, ötekilerin oldukça tehlikeli olduğunu göstermektedir. } \\
\text { Dolayısıyla, bu gösterge ötekine yönelik nefreti ve şiddeti meşrulaştırmaktadır. }\end{array}$ \\
\hline
\end{tabular}

Savaş; tarafların karşılıklı bir şekilde kuvvet kullanması şeklinde ifade edilmektedir (Keskin, 1998, s. 98). Yukarıdaki gösterge incelendiğinde; yaratığın (öteki) savunmasız yani silahsız bir şekilde asker karşısında beklediği görülmektedir. Bu da ötekilerin her ne kadar korkunç bir bedensel yapıya sahip olsa da savaş teknolojilerinden yoksun ve ilkel yaratıklar olduğunu göstermektedir. Dolayısıyla, biz'ler de ötekileri yok etmek için bu savaş teknolojilere muhtacız şeklinde bir anlam iletilmektedir. Bilindiği gibi tarih boyunca yaşanan savaşlarda silah sürekli farklı biçimlerde kullanılmıştır.

Ülkelerarası rekabetin de artmasında gelișen sanayi sonucu, savaş teknolojileri de tamamen farklı bir boyut kazanmıștır. $\mathrm{Bu}$ doğrultuda bir ülkenin gücü savunma sanayisinin gelişmişliğine de bağlı bir şekilde kendini göstermektedir. $\mathrm{Bu}$ açıdan bakıldığında, silahın gücü simgelediğini söylemek mümkündür. Görsel 5'te elinde silah bulunan üniformalı askerin yaratığa (ötekine) doğru silahını doğrultması ötekini yok etme niyetinde olduğunu göstermektedir. Burada öteki yok edilmesi gereken düşman metaforuyla sunulmaktadır.

Video oyununun ana temasında; onlar (ötekiler) kötüdür, bir tehdit unsurudur, bizlerin düzenini bozmaktadır, bizlere korku salmaktadır. Dolayısıyla ötekilerin yok edilmesi şarttır şeklinde mesajlar ön plana çıkmaktadır. Ancak, onlar kötü de olsa biz daha güçlüyüz, elimizdeki teknolojik silahlar sayesinde biz, onları (ötekileri) yok edebiliriz gibi anlamlar da iletilmektedir. Söz konusu bu noktadan hareketle, post apokaliptik temalı bu 
video oyunundaki bu öteki; silahız, teknolojiden yoksun, ilkel ama tehdit edici bir o kadar da korkunç varlıklar olarak inşa edilmektedir.

Görselde en fazla kullanılan renk; karanlık/siyah renk tonlarıdır. Bu renk Görsel 3'teki kullanıma benzer açlklanabilmektedir.

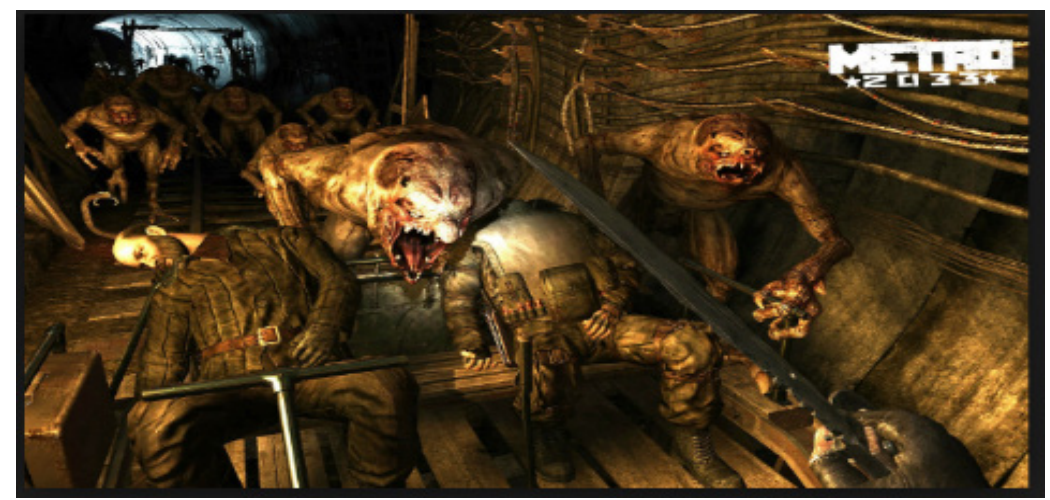

Görsel 6: Video Oyununda Bir Ötekinin İstilasına Dair Bir Gösterge

\begin{tabular}{|l|l|}
\hline 1. RENK & Koyu kahverengi tonları ( belirsizlik, sıkıntı, tedirginlik, gerilim) \\
\hline 2. GÖSTERGE & Görsel 6 \\
\hline 3. GÖSTEREN & Yaratıklar (ötekiler)/ Hançer /Asker/ Tünel/ Asker Ceseti \\
\hline 4. GÖSTERILEN & - \\
\hline 4.1. Düzanlam & $\begin{array}{l}\text { Yaratıklar (öteki) toplu bir şekilde saldırmaktadır. Bir askerse, } \\
\text { hançerle ötekilere karşı durmaya çalışmaktadır. }\end{array}$ \\
\hline 4.2. Yananlam & $\begin{array}{l}\text { Ötekilerinin sayıca fazla olması toplu istila biçiminde sunulmaktadır. Asker } \\
\text { ceseti ise ötekinin tehlikesini göstererek ötekini yok etmeyi meşrulaştırmaktadır. } \\
\text { Böylece, savaş aletlerinin kullanılması da gerekli kılınmaktadır. }\end{array}$ \\
\hline
\end{tabular}

Yay, kalkan, bıçak, hançer, savaş arabası gibi nesneler Hititlerin yazılı belgelerinde doğrudan tanrıyı temsil eden simgelerdir (Savaş, 2014, s. 228-229). Bu doğrultuda; yay, kalkan, hançer, bıçak gibi ilkel savaş aletleri tanrıyı temsil edecek kadar önemli bir güce sahiptir. Bilindiği gibi, ilk çağlardan itibaren doğaya karşı mücadele eden insanoğlu; gerek düşmanlara gerekse hayvanlara karşı gelmek için kesici aletleri üretmeye başlamışlardır. Dolayısıyla bıçak, hançer vb. gibi kesici aletlerin gücü de simgelediği söylenebilmektedir. Zira, insanoğlu, yeryüzüne geldiği ilk andan itibaren ötekileri yok etmek için çeşitli aletler kullanmış ve silahlar icat etmiștir.

Görsel 6'nın yananlam boyutuna detaylı bir şekilde bakıldığında ötekiler; ürkütücü bir biçimde sunularak yok edilmesi gereken yabani/hayvani varlıklar olarak tasvir edildiği görülmektedir. Aynı zamanda, öteki olarak nitelendirilen bu yaratıklar sürü şeklinde olup bir tehdit oluşturmaktadır. Sürü ne kadar çok birleşir ve artarsa tehdidin boyutu da o şekilde artacağına dair mesajlar iletilmektedir. Dolayısıyla bu tehditlerin yok edilmesi meşru kılınmıştır.

Video oyununun bir sahnesinde geçen bir konuşmada: "Hayatta Kalacaksak, Bu Tehdit Kesinlikle Yok Edilmeli. Neye Mal Olursa Olsun Yok Edilmeli" şeklindeki dilsel ifadelere bakıldığında, ötekilerin her ne olursa olsun yok edilmesi gerektiği gösterilmektedir. Genel bir anlatımla; ötekiler egemen gücü tehdit eden, birleşince daha güçlü olan teknolojiden yoksun hayvani varlıklar olarak sunulmaktadır. Post apokaliptik temalı bu video oyununda inşa edilen öteki yeniden düşünüldüğünde; teknolojiden yoksun, farklı, dışlanmış, tehlikeli, bedensel olarak hayvani bir biçimde sunulan ve topluluk şeklinde saldırdığında daha büyük bir tehdit unsuru olan yaratıklar olarak tasarlandığı 
görülmektedir. Ayrıca, bu ötekiler egemen güce karşı, biz'lerin yaşadığı ortama girmesine asla izin verilmeyen yani mekânsal olarak ayrıșmanın zorunlu olduğu, aşağılanmış bir alt sınıfı da temsil etmektedir.

Görüntüde yoğun olarak kullanılan renk ise kahverengidir. Bilindiği gibi kahverengi; belirsizlik, sıkıntı, tedirginlik, gerilim (Tanır, 2015, s. 192) gibi olumsuz anlamları da bünyesinde taşımaktadır.

Tablo 1: Video Oyunundaki Gösteren- Gösterilen İlişkisi

\begin{tabular}{|c|c|}
\hline Kaçış & Kurtuluş \\
\hline Yeraltı & Heterotopya \\
\hline Mutasyona Uğramış Varlık & Öteki/ Yaratık \\
\hline Asker & Koruma/Gözetim \\
\hline Sürü şeklinde yaratıklar & Korku/Gerilim \\
\hline Silah & Güç \\
\hline Kurşun & Ekonomik güç/para \\
\hline
\end{tabular}

Video oyununun içerisinde, ötekilerden kaçış bir kurtuluşa gönderme yapmaktadır. Yeraltı; insanoğlunun yaşaması gereken yerde olmadığını insanoğlunun kendini ötekilerden koruduğu heterotopik bir mekâna gönderme yapmaktadır. Bu heterotopik alan ötekilerden mekânsal ayrışmayı da zorunlu kılmaktadır.

Nükleer bir felaket sonrası mutasyona uğramış hayvan ırkı ise; tehlikeli bir yaratık (öteki) olarak sunulmuştur. Askerler ise halkın güvenliğini sağlayan ayrıca ötekileri sürekli gözetim altında tutan savaş kahramanları olarak sunulduğu görülmüştür. Sürü şeklindeki yaratıklar (öteki) ise; toplumsal düzeni bozan varlıklar olarak gösterilmekte dolayısıyla ötekilerin yok edilmesinin meşru kılındığı bir zemin oluşturulmaktadır. Bu durum, tehlikeli, biz'den olmayan ötekilerin yok edilmesini sıradanlaştırmaktadır.

Aynı zamanda, video oyununda silah ötekileri yok etmeye yarayan bir gücü; kurşun ise ekonomik bir gücü temsil etmektedir. Çünkü post apokaliptik temalı bu video oyununda kurşun para birimi olarak kullanılmaktadır. Dolayısıyla distopik bir dünyanın maddi varlığı kurşunla ölçüleceğine ve kurşunun ötekileri yok etmek için ekonomik bir güç olarak sunulacağına dair anlamlar inşa edilmektedir.

\section{Temel Karşıtlıklar/ Dizisel Çözümleme}

Așağıdaki tabloda Metro 2033 adlı video oyununda yer alan temel karşıtlıklara yer verilmektedir.

Tablo 2: Video Oyunundaki Temel Karşıtlıklar

\begin{tabular}{|c|c|}
\hline Yeryüzü & Yeraltı \\
\hline İnsan & İnsan Olmayan/Mutant \\
\hline Biz & Ötekiler/Diğerleri/Yabancı \\
\hline Erkek & Kadın \\
\hline Yaşam & Ölüm \\
\hline
\end{tabular}

Yeraltı; biz'lerin ilkel yaşamını sürdürdüğü ve ötekilerden korunduğu bir alan olurken, yeryüzü; huzursuzluğun ve korkunun hâkim olduğu bir alan şeklinde gösterilmektedir. Burada, insanoğlunun yaşamsal faaliyetleri yer altında sağlanır, yeryüzünde değil. Bu doğrultuda, her ne kadar iki karşıt mekân (yeraltı/ yerüstü) oyunda yer alsa da post apokaliptik bir dünyada artık modern yaşamın olmayacağına dair anlamların da inşa edildiği görülmektedir. 
Oyunda ayrıca insan ve insan olmayan (yaratık) şeklinde iki karşıtlık da görülmektedir. Burada insanlar; yaşaması gereken yerde (yeryüzü) olmayıp ötekilerden kurtulmak için kaçan ve ötekileri dışlayan, onları yok etmeye çalışan karakterler olarak konumlandırılmaktadır. Ötekiler ise kötü, sürekli gözetim altında tutulması gereken, tehlikeli bir o kadar da teknolojiden yoksun, aciz gruplara gönderme yapmaktadır.

Ayrıca, bu video oyununda erkek ve kadın arasında bir karşıtlığın olduğu da görülmektedir. Erkekler daha güçlü, kuvvetli, korumacı, ötekileri sürekli gözetim altına tutan bireyler olarak kurgulanırken; kadın karakterler ise oldukça güçsüz bir biçimde kurgulanmaktadır. Post apokaliptik bir dünyada hayatta kalan kișilerin, genel olarak erkeklerden oluştuğu video oyununun içerisindeki sahnelerde görülmektedir. Çünkü video oyununda kadınlar oldukça sınırlı bir şekilde temsil edilmiștir.

Oyunda yaşam ve ölüm şeklindeki temel karşıtlıklara da yer verilmektedir. Zira, oyunda yaşamak için ötekilere karşı bir nefret biçimi geliştirilerek onların/ötekilerin yok edilmesi gerektiği gösterilmektedir. Burada bir ırkçılık yaratılarak bizden olmayan ötekilerin yok edilmesi meşrulaştırılmaktadır. Irkçılığın "yaşamak istiyorsan öldür" ilkesine dayandığı söylenebilmektedir. Zira, ırkçılık yüzünden başka bir türden olmak bir suç sayılmıştır. Dolayısıyla, ırkçılık doğrultusunda da bir öteki yaratılarak "yaşamak istiyorsan öldür" politikası bu video oyununda da kendine yer bulmuştur. Bu doğrultuda, post apokaliptik bir dünyada ötekilerine yönelik nefret söylemi ve ayrımcılık yeniden inşa edilerek ötekilerini yok etme davranışı sıradanlaştırılmakta ve meşrulaştırılmaktadır.

\section{Sonuç ve Tartışma}

Teknolojinin gelişmesiyle birlikte insanoğlu teknolojiye bağımlı olmuş ve zamanla teknoloji insanoğlunu esir almaya başlamıștır. Tüm dünyayı etkisi altına alan teknoloji, insanoğluna çeşitli kolaylıklar sağlamıştır. Ancak teknolojik gelişmeler sonucunda; doğanın dengesinin bozulması, savaşların boyutlarının değişmesi, nükleer ilerlemelerin çevreye zarar vermesi ve küresel ısınma gibi felaketlerin yaşanması çeşitli olumsuz durumları da beraberinde getirmiştir. Teknolojinin getirmiş olduğu bu olumsuzluklar, insanoğlunun geleceğe yönelik tedirgin bekleyişlerine de neden olmuştur. Geleceğe yönelik bu tedirgin bekleyişler, sanal ortamlarda da kendine yer bulmuştur. Söz konusu bu durumun, sanal ortamlarda kendine yer bulması, genellikle post apokaliptik bir dünya eşliğinde sunulmaktadır. Zira, gerek sinemadaki gerekse dijital video oyunlarındaki bilimkurgu sahnelerinde yeryüzünün distopik bir alan olacağına dair anlamların sıklıkla inşa edildiği söylenebilmektedir.

$\mathrm{Bu}$ distopik alanın baş sorumlusunun ise teknolojinin olduğu ileri sürülebilmektedir. Post apokaliptik dijital video oyunlarında genellikle; teknolojik ilerlemeler sonucunda meydana gelen nükleer felaketler, doğanın dengesinin bozulması vb. gibi durumlar sonucunda yeryüzünün yaşanılmaz bir hale geldiği gösterilmektedir. Post apokaliptik dijital video oyunlarındaki yeryüzünün yaşanılmaz bir hale geldiği bu süreçte; mutantlar, yaratıklar, uzaylılar, canavarlar, siboglar şeklinde tasarlanan bir öteki inşa edilmektedir. Bu durum, bir ayrışma sürecini de beraberinde getirdiği görülmüștür.

Video oyununda inşa edilen bu ayrıșma süreci, alt tabakaların yani ötekilerin dışlanmasına yol açmıştır. Oyundaki bu ayrışma biçimine göre, ötekinin yeri normal olarak adlandırılmış bir toplumun içinde olmaz. Zira öteki, normal olana yani biz'e zarar vermektedir. Dolayısıyla; biz ve ötekiler Foucault'un da belirttiği gibi heterotopik bir alanda inşa edilmek zorundaydı. Bu durum video oyununda, biz ve ötekiler çerçevesinde; 
toplumsal ve mekânsal bir ayrıșmanın gerekliliğini de beraberinde getirmektedir. İnşa edilen bu steril alana ötekinin girmesine asla müsaade edilmediği, bunu sağlamak için de ötekilerin biz tarafından sürekli kontrol altına alınmaya çalışıldığı tespit edilmiştir.

$\mathrm{Bu}$ noktadan hareketle, biz ve ötekiler çerçevesinde bir ayrışmanın olduğu ve post apokaliptik bir dünyada da ötekilerden uzak durulduğu takdirde güvende olunacağına dair mesajlara oldukça sık vurgu yapıldığı görülmüştür. Zira ötekiler; kötü, korkunç, tehlikeli, teknolojiden yoksun ve ilkel özelliklere sahip yaratıklar olarak inşa edilmektedir.

Genel bir anlatımla; post apokaliptik dijital video oyunlarında distopik bir dünya sunulduğu ve bu dünyada da ayrımcılık, kin ve nefret kavramları unutulmayarak bir öteki yaratıldığı açığa çıkarılmıştır. Post apokaliptik temalı video oyunlarında inşa edilen ötekine yönelik eleştirel bir bakış açısı sunan bu çalışmada, öteki yeniden düşünülerek, ötekinin post apokaliptik dijital video oyunlarında nasıl sunulduğu incelenmiștir. Gerçekdışı varlık şeklindeki yaratıklar/ötekiler, aslında toplumun bir ortak korkusunun veya endișelerin bastırılması ya da toplumun ötekinden (mülteciler, diğer etnik gruplar, deliler, yoksullar, siyahiler, geri kalmış toplumlar vs.) duyduğu güvensizlik ekseninde inşa edildiği söylenebilmektedir. Söz konusu bu durum ötekinin, bir yaratık ya da canavar olarak tasarlanmasını da meșru kıldığı ileri sürülebilir.

Ayrıca, bu çalışmada insanoğlunun olması gereken yerde olmayıp heterotopik bir alanda yaşaması ve ötekilerden kaçması, ötekilerin bu alana girmesinin yasak olduğu vurgulanmaktadır. Yani ötekiler ile biz arasında mekânsal bir ayrışmanın zorunlu olduğu görülmüştür. Bu çalışmayla; post apokaliptik bir yaşamda ötekiler; kötü, tehlikeli, yabani, teknolojiden yoksun, ilkel hayvani yaratıklar olarak sunulurken, biz ise ötekilerden uzak durmaya çalışan ancak ötekileri sürekli gözetim altında tutan savaş teknolojilerine sahip olan egemen güç şeklinde sunulduğu tespit edilmiştir. Wildt ve ark'nın (2018) çalışmasında da, makineler ve teknoloji insanlardan daha akıllı, gelişmiş, yaratıcı ve güçlü bir biçimde sunulduğunun açığa çıkarılması bu çalışmayla benzer noktayı oluşturmaktadır. Bu çalışmada da makine ve teknolojiye sahip olan biz; teknolojiye muhtaç bir biçimde sunulduğu tespit edilmiştir.

Ayrıca, incelenen dijital video oyununda görüldüğü gibi post apokaliptik dünyada paranın bir değeri yoktur, değerli olan şeyler genellikle ötekini yok etmeye yarayan teknolojik araçlardır. Dolayısıyla, distopik bir dünyayla karşı karşıya kalındığı bu post apokaliptik dijital video oyununda, paranın günümüzdeki değerli eşyalarla değil; silah, kurşun vb. gibi savaş teknolojileriyle önem arz ettiği görülmüştür.

Genel bir değerlendirme yapıldığında, incelenen post apokaliptik dijital video oyununda; ideolojik mesajların sunulduğu, savaş aletlerinin önem kazandığı, bilimsel ilerlemeler sonucunda yeryüzünün yaşanılmaz bir hale geldiği, insanlığın heterotopik bir alanda yaşamak zorunda kaldığı görülmüştür. Tüm bu durumlar karşısında bir düşman algısı yaratılarak ötekileştirme politikalarının mevcut olduğu, teknolojiden yoksun alt tabaka gruplara yönelik anlamların da inşa edildiği görülmüştür. Bu ötekileștirme politikaları çerçevesinde, dijital video oyunlarında; ayrımcılık, nefret, ırkçılık ve şiddet gibi unsurlar ekseninde yok etmenin ve ayrıştırıcı politikaların meşrulaştırıldığı tespit edilmiştir. Post apokaliptik, öteki ve video oyunları üçlüsünden hareketle inşa edilen ötekine yönelik bir bakış açısı getiren bu çalışmanın, literatüre katkı açısından önem arz edeceği düşünülmektedir. 


\section{Notlar}

1 Bu çalışmada öteki olarak tanımlanan grup, ele alınan oyun (Metro 2033) içerisindeki karaderililer olarak bilinen canavarları ve mutasyona uğramış varlıkları temsil etmektedir. Çalışmadaki biz ise; öteki olmayan yani insan olan ve ötekinden uzak durmaya çalışan insan gruplarını tanımlamak amacıyla kullanılmaktadır. Bu bakımdan, Artyom ve Miller gibi ve Ranger'lar gibi oyun karakterleri, biz'i yansıtmaktadır.

2 Karaderililer şeklinde adlandırılan yaratıklar, diğer mutantların aksine daha zeki ve insanların zihinlerini okuyarak öldürme yeteneğine sahip hayvani varlıklar olarak tasarlanmışıı (Oyungezer, 2019).

3 Miller adlı karakter, Kara Derililer’i yok etmeye yetecek ateş gücüne sahip D6 adlı yer alıı füze ambarının yeri hakkında bilgi sahibidir.

\section{Kaynakça}

Adorno, T. W., \& Horkheimer , W. (2016). Aydınlanmaın Diyalektiği. İstanbul: Kabalcı Yayınevi.

Akerson, F. E. (2016). Göstergebilime Giriş. İstanbul: Azra Matbaacılık.

Altınkaya, M. T. (2016). Frankfurt Okulu'nun (Aydınlanma Eleştirisi) Penceresinden: 'The Road', 'Snowpiercer', 'Cloud Atlas' Filmleri Özelinde Distopyalar. Sine Filozofi, 49-62.

Ankara Kalkınma Ajansı. (2019, 05 10). Http://Www.Ankaraka.Org.Tr/Archive/Files/ Yayinlar/Ankaraka-Dijital-Oyun-Sektoru.Pdf adresinden alınmıștır

Barthes, R. (2018). Göstergebilimsel Serüven. (Çev. Mehmet Rifat ve Sema Rifat) İstanbul: Yapı Kredi Yayınları.

Baudrillard, J. (2010). Simülakrlar ve Simülasyon. (Çev. Oğuz Adanır). Ankara: Doğu Yayınevi.

Bauman, Z. (2003). Modernlik ve Müphemlik. İstanbul: Ayrıntı Yayınları.

Bilici, M. V. (2007). Hollywood Filmlerindeki Apokaliptik Temalar: Sinema, Popüler Kültür ve Din. Milel ve Nihal, 4(2), 139-161.

Boz, M. (2018). 2000 Sonrası Amerikan Post-Apokaliptik Bilimkurgu Sinemasında Kıyamet İdeolojisi. (Yayımlanmamış Yüksek Lisans Tezi) Ege Üniversitesi Sosyal Bilimler Enstitüsü, İzmir.

Connolly, W. E. (1995). Kimlik ve Farklılık: Siyasetin Açmazlarına Dair Demokratik Çözüm Önerileri. İstanbul: Ayrıntı Yayınları.

Cornea , C. (2007). Figurations Of The Cyborg İn Contemporary Science Fiction Novels Andfilm. D. Seed içinde, A Companion To Science Fiction. Oxford: Blackwell Publishing (s. 275-288.). Oxford: Blackwell Publishing.

Çelenk, S. (2010). Ayrımcılık ve Medya Televizyon Hanerciliğinde Etik. Ankara Üniversitesi İletişim Fakültesi, 211-226.

Çetinkaya, G. (2015). Dede Korkut Hikayelerinde Kültürel Belleğin Söylem Haritası Olarak Giyim-Kuşam ve Yeme-İçme Sembolleri. Milli Folklor, 83-96.

De Riso, G. (2013). Affect and Agency in Modern Warfare Videogames: Feeling the Muslim Enemy. Revista Alicantina de Estudios Ingleses, 143-155.

Denizel, D. (2012). Sanatın Yeni Evresi Olarak Bilgisayar Oyunları . Felsefe ve Sosyal Bilimler Dergisi, 107-143.

Devrani, A. E. (2017). Medyada “Öteki”nin Temsili: Etnik Komediler. Gümüşhane Üniversitesi İletişim Fakültesi Elektronik Dergisi, 921-949. 
Dolu, O., Büker , H., \& Uludağ, Ş. (2010). Şiddet İçerikli Video Oyunlarının Çocuklar ve Gençler Üzerindeki Etkileri: Saldırganlık, Şiddet ve Suça Dair Bir Değerlendirme. Adli Bilimler Dergisi, 5 (4), 54-75.

Ersoy, M. (2014). Oyun(cak)lardaki “Savaş” Tohumları. - i-rep.emu.edu.tr.

Foucault, M. (2005). Özne ve İktidar. İstanbul: Ayrıntı yayınları.

Göker, G., \& Keskin, S. (2015). Yabancı ve Mekânsal Ayrışma: “Distrıct 9" Filminde Heterotopik Mekân Ve İleri Marjinallik. Uluslararası Hakemli Sosyal Bilimler E-Dergisi, 428-453.

Güngör, M. (2017). Oyun Ve Üstkurmaca Bağlamında Bir Animasyon Okuma Denemesi: Wreck-It Ralph. Hikmet-akademik edebiyat dergisi (Online),, 195-204.

Hall, S. (2017). Temsil Kültürel Temsiller ve Anlamlandırma Uygulamaları. (Çev. İdil Dündar). İstanbul: Pinhan Yayıncılık.

https://tr.wikipedia.org/wiki/Metro_2033_(video_oyunu). (2020, 06 04). https:// tr.wikipedia.org/wiki/Metro_2033_(video_oyunu) adresinden alınmıştır

Jull, J. (2005). Half-Real:Video Games Between Real Rules And Fictional Worlds. . Kopenag: University Of Copenhagen Press., 163-196.

Keskin, F. (1998). Uluslararası Hukukta Kuvvet Kullanma: Savaş, Karışma ve Birleşmiş Milletler. Ankara: Mülkiyetler Birliği Vakfı Yayınları.

Kırık, A. M. (2013). Sinemada Renk Öğesinin Kullanımı - Renk ve Anlatım İlişkisi. 21. Yüzyılda Eğitim ve Toplum Eğitim Bilimleri ve Sosyal Araştırmalar Dergisi, 71-83.

Lizardi, R. (2009). Repelling The Invasion Of The "Other": Post-Apocalyptic Alien Shooter Videogames Addressing Contemporary Cultural Attitudes. Journal For Computer Game Culture, 3 (2), 295-308.

Nakıboğlu , G. (2015). Ütopyadan Doğmak, Ütopya Doğurmak: Heterotopya Kavramı ve Heterotopya Bağlamında Balık İzlerinin Sesi. FSM İlmî Araştırmalar İnsan ve Toplum Bilimleri Dergisi, 381-408.

Oyungezer. (2019, 04 14). Http://Oyungezer.Com.Tr adresinden alınmıştır

Önür, N. (2012). Türk Sinemasında Mekan ve İlişstirilmiş Kimliklerin Temsili. (ed. V. Doğan Günay ve Alev Parsa). Görsel Göstergebilim. İstanbul: Es Yayınları.

Rawi, A. (2013). Video Games, Terrorism And Jihad 3.0 Of Isıs . Terrorism and Political Violence, 30 (4).

Roloff , B., \& Seeblen, G. (1995). Ütopik Sinema. (Çev. Veysel Atayman). İstanbul: Alan Yayınevi.

Sağlık Sözlüğü. (2020, 06 03). https://saglik.sozlugu.org/heterotopia/ adresinden alınmıştır

Savaş, S. Ö. (2014). Silahlar: Hitit Tanrılarının ve Krallarının Gücü. Ankara Üniversitesi Sosyal Bilimler Dergisi, 5(2), 227-253.

Selçuk, D. (2012). Postmodern Dönemde Farklılığın Kutsanması Ve Toplumun Parçacıllaştırılması: "Öteki” ve "Ötekileştirme. Sosyoloji Araştırmaları Dergisi 15 (2), 77-99. 
Sığırcı, İ. (2017). Göstergebilim Uygulamaları Metinleri Görselleri Sanat Yapıtlarını ve Olayları Okuma. Ankara: Seçkin Yayıncılık.

Sönmeyen, D. (2016). Adorno ve Horkheimer"ın „Aydınlanmanın Diyalektiği" Eserinde Kültür Endüstrisi ve İktidar İlişkileri. Sosyal Bilimler Enstitüsü Felsefe Ana Bilim Dalı Tezli Yüksek Lisans, Mersin.

Sunato, U., \& Karadon, D. (2013). Bilim-Kurgu Sinemasında “Öteki”nin Sosyal İnşası. Vıl. Ulusal Sosyoloji Kongresi Bildiri Kitabı. Muğla.

Tanır, A. K. (2015). Frıda Kahlo’nun Umut Ağacı Adlı Yapıtı: Bir “Göstergebilim” Analizi. Sanat Yazıları (32), 185-197.

Temizkan, Ö. (2011). Öteki Tartışmaları Çerçevesinde Zygmunt Bauman’ın Öteki Yaklaşımı . Cumhuriyet Üniversitesi Sosyal Bilimler Enstitüsü, Yüksek Lisans Tezi, Sivas .

Varol, S. F. (2016). Temsil İdeoloji Kimlik. İstanbul: Varlık Yayınları.

Wildt, L., Aupers, S., Krassenve, C., \& Coanda , L. (2018). 'Things Greater than Thou': PostApocalyptic Religion in Games. Institute for Media Studies, KU Leuven, Leuven 3000, Belgium, 9(6).

Witheford, N. D., \& Sharman, Z. (2005). The Political Economy of Canada's Video and Computer Game Industry. Canadian Journal of Communication, 30 (2).

Yıldırım, H., \& Şimşek, A. (2013). Sosyal Bilimlerde Nitel Araştırma Yöntemleri. Ankara: Seçkin Yayıncılık.

Yorulmaz, B. (2018). Dijital Oyunlarda Müslüman Temsili. Medya ve Din Araştırmaları Dergisi, 1(2), 275-286.

Yürür, F. (2015). Bilimkurgu Sinemasında Güncel Korkuların Yansıması: Post Apokaliptik Filmler. (Yayımlanmamış Yüksek Lisans Tezi), Kocaeli Üniversitesi Sosyal Bilimler Enstitüsü, Kocaeli. 


\title{
Construction of "The Other" in Post-Apocalyptic Video Games: Semiotic Analysis of the Digital Video Game "Metro 2033"
}

\author{
Serkan Biçer (Asst. Prof. Dr.) \\ Yeşim Şener (Ph.D. Student)
}

\section{Extended Abstract}

The ground for a new lifestyle has been established with the development of technology in the 21st century. This lifestyle conveys a variety of messages to individuals by bringing different insights and interpretations to the fiction of the future; popular culture, language, and identity are some of the leading ingredients that are re-constructed in the frame of this fiction type. It is commonly known that negative messages such as death, blood, violence, disaster, destruction, battle, weapon, contagious diseases, and ecologic disasters are used in the process of establishing a fiction about future life stories through media in the postmodern world. In this fiction style about future, dystopian worlds involving post-apocalyptic themes and elements are created through technology.

The fear of extinction, which is the common nightmare of humanity, has increased in the postmodern world because of technology; this fear has found itself a significant place in the digital environment, in the frame of the policy of "kill to live". This virtual environment has been a place in which human beings feel more comfortable and -partially- safe. The policy of "kill to live", highly emphasized in the post-apocalyptic age, is especially used in the video games and the cruel creatures evoke the enemy defined as "the other/others". These specifically defined creatures in video games with post-apocalyptic themes are the basic reasons for a dystopian world; they not only make destruction ordinary but also establish a future that conveys the message of discrimination.

Similarly, post-apocalyptic themed future designs, especially in the frame of dystopian worlds, are presented in the video games in the digital environment; the images and ideas of "the other - stranger - the others" are carefully placed in these games to normalize discrimination. This idea of "the other" is presented in these video games as a heterotypical existence that should be destroyed.

Based on these issues, the goal of this study is to determine the position of the existences defined as "the other - stranger - the others" constructed in the post-apocalyptic video games. The study analyzes the existence of video games in terms of their relationship with today's world; it is thus important as it involves scientific data and serves as a guide to future studies on the same issue. Although there are studies in the literature focusing on the post-apocalyptic themes and the position of the other (Sunata and Karadon 2013; Cornea 2007), it was seen that there is a limited number of studies about these two concepts (post-apocalyptic and the other) in the digital games in the related literature; this is why, besides analyzing the negative consequences such as the extinction of humanity, destruction, and disaster in the post-apocalyptic themed games, it is necessary to carefully analyze the characters portrayed as "the others", which should be destroyed.

This research study, based on a qualitative method, has a case study design. It should be noted that this research design analyzes one or multiple cases in its borders in the scope of a holistic approach. The study cluster involves video games with a postapocalyptic theme; the video games analyzed for this research study were released after 
2010. The process of research was carefully conducted and different steps were taken for minimizing the limitations of video games obtained in the scope of the research. A variety of systematic standards were determined to obtain the games that serve the basic purpose of this research study. Post-apocalyptic themed video games that match the criteria of this study were chosen and analyzed. At the end of this process, the video game "Metro 2033" was chosen for the study with criterion sampling.

The obtained data will be analyzed with semiotic analysis. This analysis method will be based on denotation and connotation dimensions by considering Barthes's theory. Basic oppositions will be emphasized while conducting an in-depth analysis of the meanings. Along with determining the oppositions, meanings built on these basic oppositions will be presented in detail in the scope of the concept of "the other".

In this research study, it was observed that there is a type of discrimination as "us" and "the others" and in a post-apocalyptic world, and it is often emphasized that one can be safe when he/she stays away from "the others". These existences called "the others" are depicted as evil, terrific, dangerous, primitive beings and they don't have any technology. It was also seen that physically staying away from the others is a must according to these depictions. It was revealed that the others are never allowed to enter this sterile zone and the group named "us" constantly tries to control the others.

In general, according to the research study observations, it can be said that a dystopian world is presented in post-apocalyptic themed video games and the concepts of discrimination, vengeance, and hatred are specifically designed to be used in creating the image of "the other". It was observed that human beings aren't where they should be, they live in a heterotypical zone, they stay away from the others who are prohibited from entering the zone of "us", and it is difficult to ensure a spatial separation between us and the others. According to the analysis results, the others in post-apocalyptic worlds are presented as primitive, brutal and vicious beings while the group depicted as "us" is the dominant side who constantly tries to stay away from the others while at the same time keeping the others under control through the war technology they have.

Keywords: Postapocalyptic World, Other, Semiotics, Video Games, Metro 2033. 